\title{
Can Greenways Perform as a New Planning Strategy in the Pearl River Delta, China?
}

\section{Zheng LIU}

Email: zheng.liu@urbanstudy.net

School of Architecture, South China University of Technology, China

Department of Architecture, KU Leuven, Belgium

\section{Yanliu LIN}

Email: y.lin@uu.nl

Spatial Planning Section, Faculty of Geosciences, Utrecht University, The Netherlands

\section{Bruno De Meulder}

Email: bruno.demeulder@isro.kuleuven.be

Department of Architecture, KU Leuven, Belgium

\section{Shifu WANG}

Corresponding Author

Email: archcity@scut.edu.cn

School of Architecture, South China University of Technology, China 


\section{$1 \quad$ Abstract}

2 The modern greenway movement in China originated in 2010 when Guangdong Provincial

3 Government launched the Pearl River Delta greenway network. The PRD greenway planning has

4 strategic objectives that respond to issues associated with urbanization in the region. This article

5 presents a conceptual framework that explains the potential impact of several key factors in the planning context on the strategic uses of greenways. The framework is then applied to empirical research carried out in the PRD. The results show that greenway planning is a feasible strategy to promote rural economic development by attracting tourists and promoting the development of service sectors. In general, the PRD greenways function as a social strategy: they create new recreational spaces and provide public goods and facilities in both urban and rural areas. However, the results also show that many greenways lack landscape and ecological strategies and become primarily a transportation strategy that defines space for walking and cycling routes in urban areas. The emerging transportation-led greenways reflect the inconsistency of planning goals and outcomes, which is a compromise to both the centralized administrative system and the necessary in greenway development, insufficient social participation can undermine the achievement of the goals and priorities of the greenway plan, particularly the ecological goals and functions. How to engage local agencies, interested groups, and affected stakeholders in the planning and decision-making process has become a big challenge for greenway planning in the PRD greenways. 
9

\section{Introduction}

Greenways have a history of at least 3000 years, and include ceremonial avenues, boulevards, parkways, park belts, park systems, and green belts (Turner, 1998). The greenway movement arose as a response, driven by basic human needs, to urbanization (Searns, 1995). These needs include recreational activity and the conservation of spaces and habitats (Jongman \& Pungetti, 2004). In America, greenways - defined as "linear open spaces," "natural or landscaped trails," and "strips and linear parks" - became a national movement (Little, 1990). The primary purpose of the first American greenways was to provide connections between human settlements and the natural environment (Fábos, 1995). In Europe, greenways were developed in two contexts and had distinct functions, namely to conserve ecological infrastructures by incorporating them into an ecological network (Jongman \& Pungetti, 2004), and to provide safe and quiet routes through parks, green spaces, and streets (European Greenways Association, 2000; Transport for London, 2014b).

Because greenway resources are often concentrated in corridors, greenways are "strategic and spatially efficient for protecting and managing land" (Ahern, 2002, p. 2), In particular, protective, defensive, offensive or opportunistic strategies could be adopted in specific planning context (Ahern, 1995). In the international greenway movement, which started in the 1990s, greenways no longer had only beautification and recreational functions, but were also used to achieve multiple objectives in ecological and human dimensions (Gobster, 2014; Searns, 1995).

For over 2000 years, the historical landscapes that could now be considered greenway spaces in China were primarily linear landscapes with elements of trees and vegetation $(\mathrm{Yu}, \mathrm{Li}, \& \mathrm{Li}$, 
42 2006). Most of these linear landscapes were related to production and protection, such as the

43 protection of crops from the wind. The modern greenway movement in China started in 2010,

44 when Guangdong Provincial Government launched the Pearl River Delta (PRD) greenway

45 network as part of its urban-rural integration policy (Guangdong Provincial Government, 2010).

46 Since the economic reform in the 1980s, the PRD has undergone a bottom-up rural

47 industrialization process by attracting a large number of small-scale, labor-intensive industries.

48 This process is also called the "small city and town dominated urbanization and foreign

49 investment oriented industrialization" (Lin, 2001; Sit \& Yang, 1997). The process has promoted

50 a rapid growth in population and level of urbanization in the past three decades. Nevertheless,

51 the PRD has been confronted with many economic and development issues, for example,

52 increasingly intensified land use and a fragmented landscape, an unequal distribution of

53 resources including public goods, the challenge of industry upgrading, and urban-rural

54 disparities. Therefore, the primary purpose of the PRD greenway network was to mitigate the

55 urban-rural disparities in terms of economic, environmental, and social dimensions. By 2016,

56 over $12,500 \mathrm{~km}$ of greenways had been developed, and attracted increasing attention nationwide:

57 thirty-one provinces in China have now planned or implemented provincial greenways, and over

58163 cities are working on municipal greenways (Liu, 2017). In 2016, the Ministry of Housing

59 and Urban-Rural Development published the planning and design guidance of greenways

60 (Ministry of Housing and Urban-Rural Development, 2016), which means that the central

61 government has recognized greenways as a new national policy. 
7

The PRD Greenway Network provides an excellent case for national and international studies on greenways. As the leading project of the greenway movement in China, the PRD Greenway Network reflects some common issues of greenway planning in the specific Chinese context, such as unique institutional traditions, increasingly environmental, social and economic problems associated with rapid urbanization, and a lack of experience on greenway planning and implementation. While most greenway networks in China are still under construction and have not been incomplete, the PRD Greenway Network was already fully implemented and has led to a new greenway campaign (i.e. South China Historical Trail). Thus, it has provided valuable experience in greenway planning and implementation for other Chinese regions. In comparison with international greenways, the PRD greenways have some specific characteristics, not only because of their unique institutions and contextual issues, but also due to the high-density greenway network. For instance, the greenway density in Shenzhen reaches about $1.2 \mathrm{~km} / \mathrm{km} 2$, which is much higher than $0.3 \mathrm{~km} / \mathrm{km} 2$ density in Singapore. As a dense greenway network in a densely populated area, the problems and experience of the PRD Greenway Network nevertheless have remained under-studied.

8 The academic debates on greenways are mainly attuned to the Western context, while only a

few studies have illustrated the recent greenway movement in China. Some researchers highlight the special institutional arrangements of the PRD greenways. Xu and Yeh (2012) argue that the PRD Greenways are a result of restructuring and rescaling governance, which transforms from an internally coherent transformed system to a contested terrain. Chung, Zhang, and Wu (2018) 
6

further point out that the PRD greenways are set of politically realistic and adaptive endeavors to the powerful land interests. Meanwhile, some scholars focus on the usage of greenways. Liu, Siu, Gong, Gao, and $\mathrm{Lu}$ (2016) use the geographic information system techniques to describe the distribution of physical activities in the greenway network of Shenzhen. Their studies show that greenways with dense residences, mixed land-use, advanced street network and large parks have positive effects on supporting physical activities. Nevertheless, scholars have not yet paid sufficient attention to the relationships between development issues, institutions structures, and land interests in the planning and implementation of greenways, and their impact on the functions of greenways. The policy goal of the PRD greenway network is to mitigate the urbanrural disparities in terms of social, economic and ecological dimensions. This suggests that the PRD greenway planning may have particular strategies to deal with issues within these dimensions. Therefore, the central question of our research is that: Can greenways perform as a new planning strategy to address social, economic and ecological issues in the PRD?

To answer the mentioned question requires the formulation of a framework for understanding the relations between contexts and strategies. Based on both Western and Chinese literature, this article firstly develops a conceptual framework that interprets several key factors in the planning context that can affect the functions and strategies of greenways. This framework is original to link planning contexts and activities with strategies of greenways, which are rarely addressed in previous studies on greenways. Empirical research carried out in the PRD is then used to illustrate the framework's application. 


\section{Conceptual framework}

\subsection{Literature review on greenways}

Greenways are networks of green corridors of various widths (Fábos, 1995), which are "open spaces connector linking parks nature reserves, cultural features, or historic sites with each other and populated areas" (Little, 1990, p. 1). They contain linear elements that are planned, designed, and managed for multiple purposes (Ahern, 1995), and routes that are reserved exclusively for non-motorized journeys (European Greenways Association, 2000). Greenways have various forms, which can provide different benefits, such as ecological, environmental, social and sometimes economic functions (Smith, 1993; Erickson, 2004a). The compatible or synergistic multiple uses is one of the theoretical bases of greenways; the others are the co-occurrence of natural and cultural resources in corridor areas, and the benefits of landscape connectivity (Ahern, 2004). Researchers have recognized the multiple benefits of greenways for the integration of abiotic and biotic resources (Ahern, 1995), social exchange (Bischoff, 1995), land protection (Ahern, 2002), and collaboration between stakeholders (Ryan, Fábos, \& Allan, 2006). Greenways are seen as an overall conservation strategy, "a natural and cultural landscape matrix for which the whole is greater than the sum of the parts" (Zube, 1995, p. 22).

In the international movement, greenways are influenced by geographies, economics, culture, social and urban developments, and therefore have diverse forms (Toccolini, Fumagalli, \& Senes, 2006; Weber, Boley, Palardy, \& Gaither, 2017). In Europe, greenways developed into two distinct types, namely alternative transportation routes (Scudo, 2006) and ecological networks (Jongman, 
125

126

127

128

129

130

131

132

133

134

135

136

137

138

139

140

141

142

143

144

Külvik, \& Kristiansen, 2004; Von Haaren \& Reich, 2006). In urban areas, greenways are also used

to maximize the potential of land, for example, reserving or creating urban open spaces, especially in metropolises that were facing problems of congestion and overcrowding (Tan, 2006). They are planning tools to preserve, restore, and create green spaces in rapidly urbanizing countries, such as Brazil (Frischenbruder \& Pellegrino, 2006).

\section{Institutional tradition and historical culture of greenways in China}

In China, the historical greenways were linear landscapes alongside rivers, farmland, and transportation corridors (Yu et al., 2006). They had multiple functions, for example, urban beautification, shading pedestrians, protecting farmland, production and producing materials for defense (Luo \& Wang, 1986). In contemporary China, several top-down approaches have been employed to preserve or create greenways, such as the Three North Greenbelt which was approved by the State Council and implemented by the State Forestry Administration (Yu et al., 2006).

Besides, the National Garden City Program and the Green Channel Project could also be seen as early efforts of the greenway movement. In 1992, the National Garden City Program was initiated by the Ministry of Housing and Urban-Rural Development. It stimulated the development of urban landscapes in many cities by establishing a standard for garden cities, covering greenery and environmental development, administrative leadership, and a maintenance system (Ministry of Housing and Urban-Rural Development, 2000). 
Since 1998, the National Greening Committee, the State Forestry Administration, the Ministry of Transport, and the Ministry of Railways have issued a series of documents on the Green

148

149

150

151

152
From the National Garden City Program to the Green Channel Project, there have been continuous policy efforts in creating urban greeneries. A top-down institutional structure has been established, including the National Greening Committee in the central government and municipal departments at the local level. Consequently, urban greeneries have been institutionally developed, managed and evaluated. Both urban greeneries and institutional structures become important resources for the PRD greenways.

\section{The Definition of the Pearl River Delta Greenways}

The PRD greenways were a part of the international greenway movement. Starting in the 2000s, several Chinese scholars introduced the international greenway movement to China (e.g., Liu \& Yu, 2001; Tan \& Zhao, 2007). In January 2010, a video on international greenways was shown at a Guangdong provincial meeting. Later, the Guangdong provincial government used greenways 
167

168

169

170

171

172

173

174

175

176

177

178

179

180

181

182

183

184

185

186

187 on the east coast of the United States, the Ruhr area of Germany, and Singapore and Japan as valuable references for the PRD greenway planning.

There are several definitions of the PRD greenways in the official documents. In this article, we use the definition given by Yang Wang, who was the Guangdong Provincial Party Secretary, the initiator, and the most influential leader of the PRD greenway development. In a speech Yang Wang delivered to municipal leaders in February 2010, he adopted and combined several classic definitions (Flink \& Searns, 1993; Little, 1990) to explain the official document: "Greenways are linear green open spaces alongside natural and transportation corridors, combining avenues, nonmotorized routes, and cultural tourism routes. More specifically, greenways are: a nonpolluting commuter route, a walking or bicycle trail, a means to promote stream-water quality or to preserve wildlife habitat, a method to buffering land uses such as residential development or agriculture activity, or a way to safeguard a viewshed or the historic character of an area" (Department of Housing and Urban-Rural Development of Guangdong Province, 2014, p. 4).

1.2. A conceptual framework to understand greenways as a new planning strategy

Planning is a governance activity occurring in the complex and dynamic institutional environments, shaped by wider economic, social and environmental forces that structure specific interactions (Healey, 2003). In the field of urban planning, scholars have increasingly paid attention to how planning strategies and activities are developed to address key issues in a specific planning context (e.g. Healey, 2007; Louis, 2015). As mentioned by Leung (1985), three 
features are crucial in evaluating a planning policy, including: the consistency of values, objectives, strategies and outcomes, the adequacy of social, economic and other resources, and the dependency of the political and practical condition. However, studies on greenways have often paid attention to one specific aspect such as landscape, usage or institutional structures.

There is a lack of studies on the linkages and interactions between contextual factors and planning activities. Therefore, we developed a conceptual framework that integrates the planning context and the planning strategies, in order to understand whether greenways perform as a new planning strategy to deal with social, economic and ecological issues in the PRD (see Fig. 1).

The planning context has three key elements (scale, landscape context, and ecological, economic, and social issues), and the planning activities have four key elements (institutional structure, land acquisition, goals, and planning strategy). The mentioned key elements of the planning context and the planning activities are widely discussed in studies of greenways (e.g., Ahern, 1995; Erickson, 2004a; Linehan, Gross, \& Finn, 1995).

Figure 1 A conceptual framework: greenways as a new planning strategy

First, greenways at the regional scale require special institutional structures to coordinate the diverse actors and policies involved. In addition to policy orientation and coordination, the implementation and the management orientation are also crucial to greenway planning (Ahern, 1995). Strong centralized leadership is necessary throughout the process, in order to acquire land and sufficient funds, and for intergovernmental and interdepartmental cooperation (Erickson, 
2004b; Von Haaren \& Reich, 2006). Effective institutional structures are absent from many Western greenway practices (Erickson, 2004b; Ryan et al., 2006). In China, top-down activities have been often adopted in landscape planning. For instance, the Three North Greenbelt and Green Channel Project was effectively developed under the centralized administrative system. However, there was a lack of a scientific basis and public participation of the project (Yu et al., 2006).

Second, an in-depth understanding of the landscape context is a precondition for land acquisition. The landscape context refers to the predominant land cover of the area concerned and the predominant trends in land use change, for example urban development of forest or agricultural land (Ahern, 1995). It reflects different kinds of land use, which require specific means to obtain access to the greenway resources. In America, land acquisition often fails due to the conflict between public and private interests in land (Linehan et al., 1995; Little, 1990). Users' and residents' perceptions therefore received continuous attention (see Gobster, 1995; Gobster \& Westphal, 2004; Weber et al., 2017). In China, particular attention needs to be paid to the dual urban-rural land system. Rural land is collectively owned, whereas urban land is owned by the state and managed by the relevant municipality (Lin, De Meulder, \& Wang, 2011). A village, as a collective, can possess, use, and benefit from the ownership of land, but does not have the right to dispose of it, whereas a city can requisition a village's agricultural land and other collective land for new developments, including greenways. In rural areas and small cities, it is easy for local governments to acquire collective lands such as farmland, which is often cheap and available, for the construction of public infrastructure and facilities. Nevertheless, it is much more difficult to 
requisition collective land of villages or "villages in the city" in big cities (e.g. Shenzhen with

231

232

limited land resources), due to costly compensations and relocation programs (Hao, Sliuzas, \&

Geertman, 2011). This suggests that land requisition can become a major barrier for greenway development in urban contexts and influences greenway planning strategies and effects.

Third, issues associated with urbanization determine the goals that greenways are intended to achieve. The literature shows that greenways are usually created in response to specific ecological or social issues. For example, the increasing number of animals killed by automobiles was a primary reason to create the statewide Florida Ecological Greenway Network - an ecologically functional habitat system to mitigate the impact of roads on the habitat of species (Smith, 2004). In Singapore, an increasing need for recreational space on the heavily built-up island led to the development of greenways to connect and improve open spaces (Tan, 2006). In the PRD, the greenways are intended to mitigate the urban-rural disparities, such as economic and environmental problems, a lack of public facilities in rural areas, and a lack of recreation spaces in urban areas (Ma, 2012; Xu \& Li, 2010). The ecological, economic, and social issues thus influence the purpose of PRD greenways, which is to protect the regional ecology, improve urban livability, promote economic development, and perform a social function (Ma, 2012).

Finally, according to Ahern (1995), greenway planning can occur in four principle strategic contexts - namely protective, defensive, offensive, and opportunistic strategies - which are classified according to the attitude (proactive or reactive) and the supporting landscape 
251 (sustainable or isolated). However, these planning strategies are also about the specific goals of 252 the greenway. In China, planning is a key driver of rapid economic growth, but it has limitations 253 in achieving a more sustainable and just urban future ( $\mathrm{Wu}, 2015)$. The PRD greenways aim to 254 promote urban-rural integration and equal development in the region by providing public 255 facilities and facilitating economic transformation in rural areas (Xu \& Li, 2010). Therefore, 256 besides the mentioned landscape and ecological strategies, attention should also be paid to the 257 potential economic and social strategies of Chinese greenways.

As a result of the interrelated forces of institutional structure, the land acquisition and the planning goals, planning strategies should be evaluated for their applicability and effects on the

261 social, economic and ecological issues. Leung (1985) argues that there is a logistic need to 262 investigate whether there is relevance and causality between objectives, strategies and outcomes.

263 There is also an economic need to evaluate whether the planning arrangements are necessary and 264 sufficient. Most importantly, the key for the applicability of policy is the dependency of 265 collective recognition, which determines the political and practical support.

\section{Methods and data collection}

268 This research employs mixed methods, including documentation, semi-structured interviews, 269 questionnaires, observation, and mapping. There are three major research steps. 
First, a review of planning documents helps us to identify several key actors in the planning

272

process. With the support of local universities and governmental agencies, we conducted semistructured interviews with 12 key actors (greenway planners, officials, researchers, etc.) to understand the institutional arrangements at different levels in 2014 and 2016. Each in-depth interview lasted about 1-3 h. The contents of the interviews covered development issues in the PRD, the governmental arrangement for greenway planning, planning activities, the implementation effects, and the roles of and relationships between key actors (see Appendix).

8

Second, in order to understand the social and economic functions of greenways, we conducted several periods of in-depth fieldwork case studies in four major cities in the PRD in AprilAugust 2014, December 2014-January 2015, and November 2015-April 2016. The cases were Biotech Island, Baiyun Lake and Liantang Village in Guangzhou, Bay Park and Fenghuang Mountain Forest Park in Shenzhen, Honghua Lake in Huizhou, and Songshan Lake in Dongguan. These seven places are popular leisure and tourism spots, and have both economic and social functions. We first investigated the cases through observations and photographs to record the activities and landscape around greenways. Then we employed semi-structured interviews and questionnaires to acquire the opinions and experiences of the stakeholders. In Liantang Village, we set up three survey booths to distribute questionnaires to local residents and tourists. We invited interested users to the booths and informed them about the content of the questionnaires. The completion rate was estimated at about $80 \%$, because the number of questionnaires that respondents refused or failed to complete was not counted. In Biotech Island 
and Donghao River Greenway in Guangzhou, we distributed questionnaires and helped the respondents to complete them on site; here, the estimated completion rate was about $60 \%$. By the end of the survey, we had a total of 889 completed questionnaires from rural greenway users (477 completed by villagers and 128 completed by tourists in August 2014) and urban greenway users (284 completed by urban residents in April 2014). The questionnaires concerned such matters as the characteristics of the respondents, their opinions on greenways, and the effect brought about by greenways (recreational behavior, income, etc.), and thus provided an understanding of the greenway function from the perspective of users.

Third, Shenzhen city and Zengcheng district of Guangzhou were used as the core cases to reflect the environmental and ecological issues and recreational functions of greenways in the PRD. On the one hand, Shenzhen is now one of the leading municipalities in greenway development: By 2015, it had created 2377 km of greenways (Urban Management Bureau of Shenzhen Municipality, 2015), representing $25 \%$ of all greenways in the PRD. On the other hand, Zengcheng is used as a comparative case, which was the first area that implements greenways in China. Through field investigation in August 2014, $367 \mathrm{~km}$ of greenways and the land use in the 1000-m corridor area along the greenways were identified. We redrew the maps of the greenways in Shenzhen and Zengcheng and developed a GIS database, based on collected plans, documents, and photos, to understand the routes, categories, administrations, and forms of greenways at the municipal scale. To evaluate the environmental and recreational functions, we categorized the greenways according to their relation to the road system and the natural environment. 


\section{Empirical research in the Pearl River Delta}

315

316

\subsection{Planning context}

\section{(1) Scale}

The PRD greenways are located in one of the world's most densely populated and most dynamic economic regions (See Fig. 1). Due to rapid urbanization and industrialization, which started in the 1980s, the built-up area of the PRD grew from 4500 square kilometers in 2000 to nearly 7000 square kilometers in 2010 (World Bank Group 2015). The PRD is now the world's largest metropolitan area in terms of both size and population (World Bank Group, 2015). It has a total area of 54,754 square kilometers and comprises nine cities and 46 districts and counties that are physically separate but functionally networked. It provides housing for over 56 million people and produces 7.5\% of China's GDP (Statistics Bureau of Guangdong Province, 2015).

\section{(2) Landscape context}

There are two main types of landscape context in the PRD cities (Table 1): large forests and built-up areas. Land acquisition is very difficult, particularly in the densely built-up areas that are occupied and managed by various stakeholders. Meanwhile, the rapid urban expansion has led to severe environmental issues and there is an urgent need for environmental protection.

\footnotetext{
Table 1 The land cover of the Pearl River Delta cities, in square kilometers (2007-09)
} 
The rapid growth in population and level of urbanization in the PRD during the last three decades (Table 2) have resulted in several challenges of sustainable development (See Table 3).

First, there has been an increase in intensified land use and fragmented landscapes, while that of farmland decreased by $5.9 \%$ (Fan, Wang, \& Wang, 2008). high proportion of industry, especially in comparison to Western megacity regions (Savitch, 348 Gross, \& Ye, 2014). However, a large percentage of the industries are labor-intensive and based on foreign capital. An increase in the price of industrial land and the fierce competition from other regions, combined with many internal factors (e.g., an increase in labor costs), have forced many factories to relocate, or to plan to relocate, to other Chinese regions or other developing countries (Narayanan \& Lau, 2014). New strategies are required for economic transformation and the promotion of new economic opportunities. 
Third, there is the problem of inequality in access to public goods and facilities. Most of the developed infrastructure and facilities have catered to investment and consumption, and fewer public goods have been provided for ordinary urban residents and villagers (Eng, 1997).

Previous policies also restricted the use of bicycles and encouraged motorized vehicles, which led to the rapid decline in bicycle traffic from 30\% of the total traffic in 1980 to $8 \%$ in 2005 (Xiong, 2015; Yuan, 2015). Moreover, due to the hukou system - which registers people as either urban or rural citizens (according to their birthplace) and regulates their access to services accordingly - a large number of people (over 250 million in 2010; see Table 2) in the PRD are unregisteredhousehold migrants and thus institutionally excluded from public services in cities and villages (Lin, Hao, \& Geertman, 2015).

Finally, the unequal economic development and distribution of strategic resources have resulted in an increase in urban-rural disparities, particularly regarding income. For example, in 2009 the average per capita income (PCI) of the residents of Liantang Village in the Zengcheng district of Guangzhou (personal communication with the head of the village committee of Liantang Village, August 27, 2014), was only 15\% of the average PCI in Guangzhou (Guangzhou Municipal Statistical Bureau, 2010). The historical separation of the city and the countryside led to urban development and the neglect of rural areas; it is therefore common for rural areas to have poorer facilities (roads, parks, etc.) compared to urban areas. Since 2002, urban-rural integration has become a subject of national policy, which emphasizes the coordination of urban-rural industries and institutions (Wu, Liu, \& Cheng, 2012). 
The PRD is confronted with many development issues, for example, increasingly intensified

377 land use and a fragmented landscape, an unequal distribution of resources including public

378 goods, the challenge of industry upgrading, and urban-rural disparities. In such a context,

379 greenways are recognized as a planning strategy that can provide lowcost public goods, integrate

380 multilevel governmental resources, and coordinate urban-rural development (interview with

381 Xiangming Ma, chief planner of the Guangdong Urban \& Rural Planning and Design Institute,

382 July 3, 2014).

383

3.2. Planning activities

Figure 2 The Pearl River Delta Greenway Network

(1) Goal

According to the Outline Plan of the PRD Greenway Network 2012, the main goal of the greenway planning is to address the ecological, social, and economic issues associated with rapid urbanization, that is, to improve the ecological environment, enhance the quality of life, and

392 promote economic development (Department of Housing and Urban- Rural Development of

393 Guangdong Province, 2014, p. 250). Meanwhile, the regional greenway network was to be 394 completed within three years and become the province's flagship project (Department of

395 Housing and Urban-Rural Development of Guangdong Province, 2014, p. 1). However, the 
three-year timeframe was over-optimistic, as the greenway plan lacked detailed action plans,

397 particularly from the ecological perspective.

\section{(2) Land acquisition}

400 Land acquisition in Western countries is beset by conflicts between public interests and 401 private rights (Little, 1990). Greenways are opposed by local stakeholders, because of the

402

403

404

405

406

407

408

409

410

411

412

413

414 green corridors in the built-up areas. 
Therefore, at the beginning of greenway planning, the regional actors already recognized the

417

418

419

420

421

422

423

424

425

426

427

428

429

430

431

432

433

434

435

436

importance of land acquisition. According to an article published in Southern Weekly (one of the

official Guangdong Communist Party newspapers), there were two primary challenges for

greenways development, namely of the collaboration between different levels of government and

the acquisition of land resources (He \& Guo, 2010). Municipal governments usually spend their

limited land quota in projects that could generate revenue, rather than non-profitable projects like greenways (Chung et al., 2018). Consequently, they refuse to acquire land in built-up areas, but utilize resources that are state-owned and over which there is a public right of way, such as corridors alongside motorized roads, rivers, and reserved areas. In this way, local governments can "avoid consuming local construction land quota as far as possible" (Department of Housing and Urban-Rural Development of Guangdong Province, 2014, p. 315).

In rural areas, the municipal or district government has to negotiate with each village separately. Some villages oppose greenways, because they fear interference and additional regulations, and most important, they do not believe that greenways will bring them benefits. For example, the village committee of Shatou Village in Zengcheng (a district of Guangzhou city) at first refused to allow a greenway to enter the village (interview with public authorities in Zengcheng Urban Planning Bureau, June 30, 2014). In order to get the village's support, the district government funded the construction or upgrading and maintenance of village infrastructures, such as trails, sanitation facilities, and landscaping. The government also provided grants to villagers to cultivate ornamental vegetation and create recreational spaces 
437 (right-hand photo in Fig. 3) (interview with public authorities in Zengcheng Urban Planning

438 Bureau, June 30, 2014). For example, a part of the greenway passes through a lychee orchard,

439 resulting in the creation of a small lychee market for the orchard owners, a recreational space for

440 villagers, and a scenic spot for tourists (left-hand photo in Fig. 3). This approach of offering

441 public facilities, governmental grants, and other economic benefits does not change the land

442 ownership, but it does encourage villages to cooperate with the city government (interview with

443 the head of the village committee of Liantang Village, August 27, 2014).

445 Figure 3 Collectively owned lychee orchard and lotus ponds as a shared landscape in Zengcheng,

446 Guangzhou

447

448

(3) Institutional structure

449 The Provincial Party Committee Secretary established the Guangdong Greenways

450 Construction Committee to promote, assign, and supervise greenway development. Every month,

451 the committee publicly ranked municipalities according to the length of greenway developed in

452 the previous month, the total length of greenery developed, and the number of service stations,

453 demonstration projects, and intercity connecting points (Department of Housing and Urban-

454 Rural Development of Guangdong Province, 2014, pp. 60-63). This process is also called as "the

455 centralized planning regulation", influenced by "a massive top-down state regime” (see Xu \&

456 Yeh, 2012). 
However, the implementation of the PRD greenways was widely decentralized. According to our interviews with greenway offices from several public authorizes in provincial, municipal and town governments, assignments and plans were subcontracted to district, township, or town governments, which in turn subcontracted them to sub-district offices and bureaus of landscape, water resources, forest, and transportation (See Fig. 4). For example, in Shenzhen there are over 50 governmental units working on the $2265 \mathrm{~km}$ of greenways (Urban Management Bureau of Shenzhen Municipality, 2015). Although these units have different administrative functions, they now perform additional greenway tasks related to investment, development, management, and maintenance in their own jurisdictions.

Influenced by the institutional structure, a three-tier greenway network was established,

471 whereby the provincial greenways are the primary intercity connections, and the municipal and

472 community greenways are at the inner-city and the inner-community level, respectively. In

473 addition, the greenways making up the network are also classified as urban, countryside, or

474 ecological greenways. As a result of intergovernmental competition, the municipal and

475 community greenways now dominate the official plans (Department of Housing and Urban-

476 Rural Development of Guangdong Province. (2011), 2011, 2014, p. 322-325). 
478 Table 3 The projected length of regional, municipal, and community greenways in the Pearl

479 River Delta by 2015, in kilometers

480

481

\section{Greenways as a New Planning Strategy}

482

4.1. Greenways as a social strategy: compensatory public goods

483

Villages and urban-rural fringes have a huge number of low-income villagers and

marginalized rural migrants, and they lack sufficient public spaces and facilities (Lin \& De

Meulder, 2012). Greenways bring with them government money for parks, street greenery,

bicycle routes, and public bikes. From this perspective, the PRD greenways have a social

487 function, providing compensatory public goods for less developed areas in both urban and rural

488 areas.

One of the basic social benefits of the PRD greenways is to provide new bicycle and pedestrian routes in areas where there are pedestrian-vehicle mixed flows or inaccessible. For example, in Shenzhen's Xingye Road and Xingping Road, the greenways were implemented as new sidewalks, providing pedestrians and bicyclists with a certain level of protection (Fig. 5). The improvement of bicycle routes has facilitated the widespread use of public bikes in both urban and rural areas and the possibility to travel by bike arose rapidly in China (See Fig. 6). For example, a recent report shows that in Shenzhen, there are over 530,000 shared bicycles and cycling and their percentage of the total traffic has increased from $8 \%$ to $10.7 \%$ (Transport Commission of Shenzhen Municipality, 2017). 
Figure 5 Street views before (left, 2011) and after (right, 2014) the implementation of the greenways in Shenzhen's Xingye Street (above) and Xinping Street (below).

Figure 6 Public bikes in racks next to a community greenway in Yantian District, Shenzhen

Another basic social benefit is to provide recreational spaces, especially in those areas where there is a lack of public facilities. As Liu et al. (2016) revealed, greenways are now important spaces for physical exercise. During our field investigation in August 2014, we found that greenways had strongly promoted outdoor leisure activities in villages. In Liantang Village, for example, $42 \%$ of the 127 local villagers we interviewed chose "outdoor exercise" as the primary reason why they used nearby greenways. When asked "How often did you engage in outdoor leisure activities five years ago?", $31 \%$ chose "almost never", compared to only 7\% when asked “How often do you engage in outdoor leisure activities now?” (questions 8-10 in Table 4).

Since 2016, the social function of greenways has been strengthened, because greenways are now performing as a special means of "Targeted" Poverty Alleviation policy (jingzhun fupin). In the new greenway scheme - "South China Historical Trails (nanyue guyidao)", both historical heritage protection and rural poverty alleviation are emphasized. The provincial government announced that, the 1360 poverty-stricken villages along the planned trails would enjoy higher priorities in public budgets (Guangdong Provincial Government, 2017). Moreover, Guangdong government set up a special fund of CNY 500 million (USD 75 million) for maintenance of 
520 historical trails and construction of infrastructure. In the PRD, greenways are viewed as a sign of

521 policies shifting from growth-oriented development to a slower but more balanced mode

522 (Department of Housing and Urban-Rural Development of Guangdong Province, 2014, p. 2).

523 The network form of greenways contributes to decrease the inequity of government investment

524 between central and peripheral areas, and between urban and rural areas. To some extent,

525 greenways act as special compensations to those places that received less government funds and

526 to those people who did not have access to recreational resources.

527

528

529

530

531

532

533

534

535

536

537

538

539

540
In the PRD, greenways are viewed as a sign of policies shifting from growth-oriented development to a slower but more balanced mode (Department of Housing and Urban-Rural Development of Guangdong Province, 2014, p. 2). The network form of greenways contributes to decrease the inequity of government investment between central and peripheral areas, and between urban and rural areas. To some extent, greenways act as special compensations to those places that received less government funds and to those people who did not have access to recreational resources.

\subsection{Greenways as an economic strategy: rural economic transformation}

Greenways play an important role in the economic transformation of some rural areas in the PRD, through increasing job opportunities in the tertiary sector. Due to a close proximity of beautiful natural resources, these greenways have attracted a large number of local residents and tourists and thus contributed to local economies in many ways. For example, our fieldwork in 
541

542

543

544

545

546

547

548

549

550

551

552

553

554

555

556

557

558

559

560

561

Xinan Village, which is close to the Jinzhong reservoir in Zhongshan city, reflects that bicycle rental is becoming an important source of income for the village. Around the entrance of Jinzhong greenway, there are over 40 villager-owned bicycle rental stores (right in Fig. 7). There are thousands of bicycles in the stores and the rent of one bicycle for a day ranges from CNY 10 (USD 1.5) to 20 (USD 3). The interview (February 6, 2016) with a manager of a bicycle rental store show that a store can earn monthly income about CNY 1000 (USD 149) in off-season and over CNY 5000 (USD 746) in peak seasons.

Figure 7 Jinzhong greenway (left) and bicycle rental stores at the entrance (right)

Another interesting case is Liantang village of Guangzhou. Villagers benefit from tourism restaurants and supported policies. Since 2010, the greenways of the village have attracted over 400,000 tourists every year, so 30 villager-owned restaurants have been opened to cater the tourists. This results in changes in the village's economy and an increase of the villagers' income. According to our interview with seven managements of six restaurants along the main street of the village, most of the owners were once migrant workers in the city. This suggests that greenways provide new employment opportunities for villagers, i.e. they can now work in their hometowns rather than migrating to the city. As managers of restaurants, they often have a higher income than that of their previous jobs. For example, Zhikang Qiu, who worked in the city for two years, returned to Liantang village and now runs a new restaurant. The financial recourses include his saving and a special fund from the government that supports the 
562

563

564

565

566

567

568

569

570

571

572

573

574

575

576

577

578

579

580

581

582

employment of villagers along the greenway. The restaurant of Mr. Qiu has become one of the most successful restaurants in the village and earns over CNY 1 million (USD 160,000) per year. Inspired by Qiu, many villagers, who were migrant workers in the city, have returned to work in Liantang village.

In Liantang Village, Qiaotou Village, and Hezhou Village (Zengcheng district, Guangzhou), 478 tourists and 127 villagers completed questionnaires at our three survey booths (see Table 4).

Their responses show that the natural environment and views of the countryside attracted a large number of tourists from nearby cities and districts (questions $1 \&$ 2). During 2010 to 2014, the percentage of villagers who had an annual household per capita income (PCI) of less than CNY 10,000 (USD 1490) had dropped from $52 \%$ to $38 \%$. Over the same period, the percentage who had an annual household PCI of over CNY 50,000 (USD 7400) had increased from $11 \%$ to $26 \%$ (questions 3 \& 4). The interview (on August 27, 2014) with the head of Liantang Village showed that the annual household PCI had increased from CNY 5000 (USD 740) in 2009 to CNY 15,000 (USD 2200) in 2014 due to the development of greenways. The economic growth mainly came from 30 self-owned tourism restaurants, which provided new sources of income and employment. The outcomes of these questionnaires further proved the influence of greenways on local employment. For instance, $26 \%$ of the villagers worked in the emerging restaurants, while the percentage of outworkers and farmers in the total population had decreased from 53\% to $43 \%$ and from $33 \%$ to $18 \%$, respectively (see questions $5 \& 6$ ). This suggests that the greenways had facilitated the transformation of the local rural economy from agriculture to service sector. All in 
583 all, villagers considered increased income and the availability of daily exercise spaces the

584 primary benefits of greenways (see question 7).

585

586 Although greenways' economic benefits on property value have been heavily investigated (see

587 Noh, 2019), it has not been proved in the PRD greenways. In this research the economic benefits

588 are only found in rural areas that did not establish an industrialized economy, so that the villagers

589 have limited incomes, and the agriculture landscape remains intact and unpolluted. So far, the

590 primary benefits come from the increasing incomes of tourism business and more opportunities

591 in local employment. From this perspective, greenways are performing as a crucial strategy in

592 rural economic transformation, with more potentials to be discovered.

Figure 8 Greenway tourists riding public quadricycles past restaurants in Liantang Village

Table 4 The questionnaires used in Zengcheng, Guangzhou

\subsection{Lack of ecological and landscape strategies}

599 The PRD greenways were initiated in a protective context addressed by Ahern (1995), but

600 there has been generally a lack of ecological and landscape strategies. Regarding the corridor

601 areas along greenway routes, the greenway planners propose the official concept of Greenway

602 Protected Area (Department of Housing and Urban-Rural Development of Guangdong Province,

603 2014, pp. 448-451). The concept aims at establishing a network of green corridors through 
604 prohibiting building construction in 20-to-200-m wide corridors along greenway routes. But in

605

606

607

608

609

610

611

612

613

614

615

616

617

618

619

620

621

622 In Shenzhen, 70\% of the greenways were in built-up areas (Fig. 9). According to our

623 investigation, off-road greenways comprise $16 \%$ of the total, in-roadway greenways $17 \%$, and

624 on-sidewalk greenways $67 \%$. An important result is that $43 \%$ of the greenway corridors are less

greenway planning it rarely focuses on developing new corridors or extending existing green

spaces, which only fits to the protective context. However, even though, most cities follow the

provincial guidance, which requires provincial and municipal greenways to connect with the

mentioned greenway protected areas. Community greenways, which make up the majority of the

PRD greenway network, are mainly walking or cycling routes with few or no control areas.

There is a lack of concerns on construction control, landscape and greenery in the corridor area,

which is the basis of the landscape and ecological strategy. In the end, the primary landscapes

along greenways come from existing street trees and vegetation, but whether these narrow

landscapes can provide anticipated ecological benefits (i.e. increasing biodiversity) and perform

as recreational resources remains unanswered.

Guangzhou and Shenzhen are two good examples to reflect this issue. Through field

investigation and mapping, we identified $1935.9 \mathrm{~km}$ of greenways in Shenzhen and $367 \mathrm{~km}$ of

greenways in Zengcheng district of Guangzhou. We categorized the greenways as offroad

greenways which are outside of transportation corridors but often inside of green corridors, in-

roadway greenways, and on-sidewalk greenways (Fig. 10). 
625 than $3 \mathrm{~m}$ wide and $18 \%$ are $3-12 \mathrm{~m}$ wide. This suggests that the greenways have little ecological

626 value, because green corridors that are less than $12 \mathrm{~m}$ wide can hardly improve biological

627 diversity, according to the official greenway guidance (Department of Housing and Urban-Rural

628 Development of Guangdong Province, 2014, p. 425). In addition, these narrow corridors of street

629 greenery are useful in providing shading to non-motorized travelers, but have little effects on

630 decreasing noises and smells caused by vehicles, based on our observation in the fieldwork.

631 Through comparison of images before and after greenway development, we found that $56.5 \%$ of

632 the greenways were actually public infrastructure (e.g., sidewalks, trails, and motorized roads)

633 with greenway symbols, and that $43.5 \%$ of the greenways are repaved or newly developed. The

634 pavement of the existing sidewalks nevertheless has led to a new problem. Many greenways are

635 not only indistinguishable from ordinary sidewalks, but also are difficult to be used for outdoor

636 exercise and cycling. The problem of greenways in Shenzhen is properly caused by limited land

637 resources in the city and difficulties in requisitioning collective land for the development of

638 greenways.

639

$640 \quad$ Figure 9 Shenzhen greenways overlaid with built-up area

641

642 Figure 10 Typology of greenways in Shenzhen

643

644 Table 5 Detailed data of Shenzhen greenways 
In Zengcheng district of Guangzhou, we identified $367 \mathrm{~km}$ of greenways and mapped land use

647 types in the 1000-m-wide corridors along greenways (left in Fig. 11). Comparing with Shenzhen, 648 Zengcheng district has more natural resources and wider greenway corridors. Our mapping 649 reflects that $66 \%$ of the corridors is natural green spaces and $66.5 \%$ of greenways have green 650 corridors with a width of more than $100 \mathrm{~m}$. However, the landscape contexts of greenways are 651 quite different. Some greenways are developed in densely built-up areas (area 6 in Fig. 11), 652 while some are located in farmlands (area 1 and 2 in Fig. 11). Although the greenway corridors 653 have natural supporting landscape, the proportion of off-road greenways is still comprised of $65415 \%$, close to that of Shenzhen. Like greenways in many cities in the PRD, most of the 655 greenways (85\% in Zengcheng and $84 \%$ in Shenzhen) are overlapped with transport corridors,

656 which can reduce the ecological function of greenways.

Therefore, based on the case studies of Shenzhen and Zengcheng, as well as our observations of other greenways in the region, we conclude that the majority of the PRD greenways are developed among transport corridors. The primary action is the construction of cycling routes, while there is a lack of concern on landscape and ecological aspects. However, this research primarily focuses on the consistency between official guidance and practical outcomes. Future evaluation on the ecological biodiversity, environmental improvement or stormwater management could be useful evidence to validate our arguments. 
666

667

668

669

670

671

672

673

674

675

676

677

678

679

680

681

682

683

684

685

Figure 11 Zengcheng greenways and land use types in the 1000-meter-wide corridors along greenways

\section{Discussion}

In the PRD greenway planning, the official stated goals aim at improving the ecological environment, enhancing the quality of life, and promoting economic development. Our research shows that, to some extent, the PRD greenways bring social and economic benefits to the region through providing public facilities (i.e. public bikes, bikeways and exercise facilities) and promoting tourism economy in some less developed villages. However, there is inconsistency between goals and outcomes of the overall greenways. The empirical works in Guangzhou and Shenzhen show that, although the greenways were planned as a special instrument to bridge the urban-rural divide, in practice only some cases show that greenways function as linkages between urban and rural settlements. Most greenways (i.e. community greenways) are implemented in urban areas and are comprised of walking and cycling routes. This suggests that greenways become a transportation strategy. Moreover, the ecological objective of greenways is hardly achieved, since most greenways do not have an adequate corridor. There are several reasons for the inconsistency between goals and outcomes, including inadequate supporting resources, a short time frame, and the excessive dependency of institutional arrangements. 
The primary reason is that the supporting resources and budget are inadequate to accomplish

687 the ambitious goals in such a tight schedule. The context of the PRD Greenway Network is

688 characterized by a densely built-up landscape and a high population density. To use Ahern's

689 planning strategies (1995), the PRD greenways are operating in a very defensive strategy, and

690 with high competition for greenway space. This suggests that it is a big challenge to mitigate

691

conflicts over natural resources and develop ecological greenways. This context is different from

692

that in many Western countries. For instance, greenways in the United States are usually

693

developed on residual leftovers and abandoned linear corridors (Walmsley, 1995), in which

694

corridors are key elements of multi-purpose greenway planning (Conine, Xiang, Young, \&

695

Whitley, 2004). In the PRD, the landscape contexts, especially land resources, act as a major

696

constraint for achieving the ecological goal of greenways. Although regional governments

697

develop various greenway models in order to achieve the ecological goals, local governments

698

that are operating under governmental pressure from the centralized administrative system have

699

to construct the greenways in a short period with limited land resources and budgets. Especially

700

in big cities, the lack of cheap and available lands, and the unwillingness of governments to re-

701

appropriate already developed lands for greenways, has impeded the implementation of

702

ecological and landscape strategies. In fact, during the planning process, there should have been

703

more efforts of evidence-based findings to support the decision-making, so that the unrealistic

704 ecological objectives could be avoided, considering such a short time frame and insufficient

705 landscape resources. 
707

708

709

710

711

712

713

714

715

716

717

718

719

720

721

722

723

724

725

726

727

17

18

5.2. Excessive dependency of centralized administrative system

The rapid development of greenways in the PRD is largely attributed to the centralized administrative system. There are strong leadership in the development of PRD greenways, which is often missing in the Western context (Erickson, 2004a; Ryan et al., 2006). However, the importance of practical ability is widely overlooked. On the one hand, the planners have little influence on the implementation, because of the absence of detailed action plans. On the other hand, the limited budget of greenway projects cannot afford experienced planners and designers.

Therefore, the local-level governmental units become the primary actors of greenway implementation (see Table 5), which have various administrative duties and often lack professional skills and experiences of greenways.

Although the knowledge from interested professionals and social groups is required for greenway planning, the centralized institutional structure does not provide necessary accesses for their participation. In western countries, greenway organizations play a crucial role in initiating greenway programs, applying for funds and managing greenways, such as East Coast Greenway Alliance and Atlanta Development Authority in the United States. In China, although there has been an increase in the number of interested professionals, most of them are unable to acquire financial supports and have not participated in the greenway planning and implementation (interview with the planner of the Institute for Transportation and Development Policy in Guangzhou in September 2016). 
728

729

730

731

732

733

734

735

736

737

738

739

740

741

742

743

744

745

746

747

748

5.3. Emerging transportation-led greenways in the world

As shown in the empirical works, the development of the PRD greenways reveals a new type of greenway development, namely of transportation-led greenways. It has been overlooked for years until recently some researchers referred it as "new urban greenways", which are "landscaped and traffic-calmed pathways with a mix of bicycle facilities and other streetscape improvements" (Ngo, Frank, \& Bigazzi, 2018, p. 716). A few studies on greenways in London, Singapore, and Oranienburg show that it is easy to require land resources for greenways along the road traffic networks (Bloß, 2016; East Coast Greenway Alliance, 2016; Tan, 2006;

Transport for London, 2014a,b). But these greenways also raise a new question: How to achieve multiple benefits in the built-up traffic corridor? In some cases, for example in London, greenways have adopted new meanings, for example "quietways," with a focus on the transportation or recreational function in the urban landscape. Other cases start with traffic-based routes but with an emphasis on separating the greenways from motorized traffic step by step. Research reflects that mixed traffic imposes a sense of threat and high emotional stress on bicycle users (Chataway, Kaplan, Nielsen, \& Prato, 2014), while off-road bicycle routes can increase bicycle traffic by 332\% (Hankey et al., 2012). The East Coast Greenway Alliance is developing a long-distance, off-road travel route. It has already completed $1408 \mathrm{~km}$ of off-road greenways, and there are still $3277 \mathrm{~km}$ of in-road routes to be improved (East Coast Greenway Alliance, 2016). Regarding these greenways, transport usage requires more concerns on cycling design, such as safety, directness, comfort, coherence, attractiveness and adaptability (see Transport for London, 2014a,b), which are also urgently needed in the PRD greenways. 
750 In the end, because of the inadequate planning resources, the centralized administrative system

751

752

753

754

755

756

757

758

759

760

761

762

763

764

765

766

767

768

769

and the need for non-motorized transportation, the PRD greenways have apparent inconsistency

between goals and outcomes. However, the PRD greenways, as a part of the international

movement, shows a great adaptive capacity of the greenway concept in which publicity and

inclusiveness are key values.

\section{Conclusion}

For many greenways in western countries, effective institutional structures are necessary, not

only because of the need to coordinate inter-agency cooperation, but also in order to focus

stakeholder interests towards a targeted goal (Erickson, 2004b; Ryan et al., 2006). This research

contributes to the international debate on greenways in the following aspects. First, the PRD

greenways show new approaches, outcomes and issues of greenway planning, which is largely

caused by the specific centralized Chinese planning and administrative system context. The PRD

greenways reflect that the centralized institutional structure that is characterized by strong

leadership plays a significant role in mobilizing multi-level governments and agencies,

integrating government resources, and establishing a long-term institutional structure. Second,

although there is generally a lack of landscape and ecological actions in greenway planning, the

PRD greenway can be seen as a successfully social strategy by providing public infrastructure,

facilities and recreation spaces for both urban and rural areas and mitigating the gaps between

these two areas in terms of public goods. Future research is recommended to document the extent 
770

771

772

773

774

775

776

777

778

779

780

781

782

783

784

785

786

787

788

789

790

that the PRD greenways provide ecological and hydrological function. In some rural areas, greenways also perform as an economic strategy through promoting tourism economy and providing new job opportunities to local villagers. In urban areas, many greenways have become a new transportation strategy that defines space for walking and cycling routes. Third, the research reveals that one of the main issues of the centralized institutional structure is how to engage local agencies, interested groups and greenway stakeholders in the planning process. To solve this issue will improve the consistency of achieving targeted goals and conducting effective planning activities. In the PRD greenway movement, local agencies were widely mobilized because of administrative pressures. In the recent development of South China Historical Trails, the regional leaders have begun to recognize the importance of local agencies in a regional greenway scheme. With a similar centralized structure, they have changed the governance mode from a top-down administrative system to a more collaborative approach based on competitive applications for funds. Provincial departments and local agencies sign contracts that have clear agreements on yearly objectives, under the supervision of over 300 volunteering experts of urban planning, architecture and tourism. This collaborative approach has largely increased the willingness of local agencies to participate in the planning process. However, how to engage the interested groups and affected stakeholders in the decision-making and implementation stages has still been a big challenge in greenway planning.

\section{References}

Ahern, J. (1995). Greenways as a planning strategy. Landscape and Urban Planning, 33 (1-3): 
131-155. https://doi - 10.1016/0169-2046(95)02039-V.

Ahern, J. (2002). Greenways as strategic landscape planning: theory and application (Doctoral dissertation). Wageningen University, the Netherlands.

Ahern, J. (2004). Greenways in the USA: theory, trends and prospects. In R. H. G. Jongman (Ed.), Ecological networks and greenways: Concept, design, implementation (pp. 34-55). Cambridge: Cambridge University Press.

Bischoff, A. (1995). Greenways as vehicles for expression. Landscape and Urban Planning, 33 (1-3): 317-325. https://doi - 10.1016/0169-2046(94)02025-B.

Bloß, L. (2016). A greenway for sustainable mobility (Mater Thesis). Technische Universität Berlin. www.landschaft.tuberlin.de/fileadmin/fg218/Publikationen/LisaBlo\%C3\%9F_2016_GreenwaysOranienburg.p df

Chataway, E. S., Kaplan, S., Nielsen, T. A. S. \& Prato, C. G. (2014). Safety perceptions and reported behavior related to cycling in mixed traffic: A comparison between Brisbane and Copenhagen. Transportation Research Part F: Traffic Psychology and Behaviour, 23: 32-43. https://doi - 10.1016/j.trf.2013.12.021.

Chung C.K.L., Zhang F. and Wu F. 2018. Negotiating Green Space with Landed Interests: The Urban Political Ecology of Greenway in the Pearl River Delta, China. ANTIPODE. Online Version. https://doi - 10.1111/anti.12384

Conine, A., Xiang, W., Young, J. \& Whitley, D. (2004). Planning for multi-purpose greenways in Concord, North Carolina. Landscape and Urban Planning, 68 (2-3): 271-287. https://doi - 10.1016/S0169-2046(03)00159-2.

Department of Housing and Urban-Rural Development of Guangdong Province (2011). Master Plan of the Pearl River Delta Greenway Network: urban and community greenway (draft). (in Chinese)

Department of Housing and Urban-Rural Development of Guangdong Province (2014). Memoir of Guangdong Greenway Network Planning and Construction. Beijing: China Architecture 
\& Building Press, China City Press. (in Chinese)

Department of Land and Resources of Guangdong Province (2006). Guangdong province land use planning (2006-2020). (in Chinese)

Department of Land and Resources of Guangdong Province (2011). Guangdong province land remediation planning. (in Chinese)

East Coast Greenway Alliance (2016). 2015 Annual Report. Www.greenway.org/pdf/2015_annualreport.pdf

Eng, I. (1997). The rise of manufacturing towns: externally driven industrialization and urban development in the Pearl River Delta of China. International Journal of Urban and Regional Research, 21 (4): 554-568. https://doi - 10.1111/1468-2427.00101.

Erickson, D. L. (2004a). Connecting corridors: implementing metropolitan greenway networks in North America. In R. H. Jongman and G. Pungetti (Eds.), Ecological networks and greenways: Concept, design, implementation (pp. 200-221). Cambridge: Cambridge University Press.

Erickson, D. L. (2004b). The relationship of historic city form and contemporary greenway implementation: a comparison of Milwaukee, Wisconsin (USA) and Ottawa, Ontario (Canada). Landscape and Urban Planning, 68 (2-3): 199-221. https://doi - 10.1016/S01692046(03)00160-9.

European Greenways Association (2000). Declaration of Lille. European Greenway Association. from http://www.aevv-egwa.org/conference2010/dmadrid/dm_eng.pdf.

Fábos, J. G. (1995). Introduction and overview: the greenway movement, uses and potentials of greenways. Landscape and Urban Planning, 33 (1-3): 1-13. https://doi - 10.1016/01692046(95)02035-R.

Fan, F., Wang, Y. \& Wang, Z. (2008). Temporal and spatial change detecting (1998-2003) and predicting of land use and land cover in Core corridor of Pearl River Delta (China) by using TM and ETM+ images. Environmental Monitoring and Assessment, 137 (1-3): 127-147.

Flink, C.A. \& Searns, R.M. (1993). Greenways: a guide to planning design and development. 
Island Press.

Frischenbruder, M. T. M. \& Pellegrino, P. (2006). Using greenways to reclaim nature in Brazilian cities. Landscape and Urban Planning, 76 (1-4): 67-78. https://doi 10.1016/j.landurbplan.2004.09.043.

Gobster, P. H. (1995). Perception and use of a metropolitan greenway system for recreation. Landscape and Urban Planning, 33 (1-3): 401-413. https://doi - 10.1016/01692046(94)02031-A.

Gobster, P. H. \& Westphal, L. M. (2004). The human dimensions of urban greenways: planning for recreation and related experiences. Landscape and Urban Planning, 68 (2-3): 147-165. https://doi - 10.1016/S0169-2046(03)00162-2.

Gobster, P. H. (2014). (Text) Mining the LANDscape: Themes and trends over 40 years of Landscape and Urban Planning. Landscape and Urban Planning, 126: 21-30. https://doi 10.1016/j.landurbplan.2014.02.025.

Guangdong Provincial Government (2010). Pearl River Delta Urban-rural Planning Integration Plan 2009-2020. zwgk.gd.gov.cn/006939748/201801/t20180113_748466.html (in Chinese)

Guangdong Provincial Government (2017). The working scheme of South China Historical Trails 2017. zwgk.gd.gov.cn/006939748/201705/t20170524_706615.html (in Chinese)

Guangzhou Municipal Statistical Bureau (2010). Guangzhou statistical year book 2010. Beijing: China statistic press. (in Chinese)

Hankey, S., Lindsey, G., Wang, X., Borah, J., Hoff, K., Utecht, B. \& Xu, Z. (2012). Estimating use of non-motorized infrastructure: Models of bicycle and pedestrian traffic in Minneapolis, MN. Landscape and Urban Planning, 107 (3): 307-316. https://doi 10.1016/j.landurbplan.2012.06.005.

Hao, P., Sliuzas, R. \& Geertman, S. (2011) The development and redevelopment of urban villages in Shenzhen. Habitat International, 35(2):214-224.

He, H. \& Guo, H. (2010, February 28). Greenway planning: the biggest challenge is the officials, and the biggest problem is the land. Guangzhou: Southern Weekly, C16. (in Chinese) 
Healey, P. (2003). Collaborative planning in perspective. Planning Theory, 2(2):101-123.

Healey, P. (2007). Urban Complexity and Spatial Strategies: Towards a Relational Planning for our Times. New York: Routledge.

Jongman, R. H. G., Külvik, M. \& Kristiansen, I. (2004). European ecological networks and greenways. Landscape and Urban Planning, 68 (2-3): 305-319. https://doi10.1016/S0169-2046(03)00163-4.

Jongman, R. H. \& Pungetti, G. (2004). Introduction: ecological networks and greenways. In R. H. Jongman and G. Pungetti (Eds.), Ecological networks and greenways: Concept, design, implementation (pp. 1-6). Cambridge: Cambridge University Press.

Leung, HL. (1985). Towards a Subjective Approach to Policy Planning \& Evaluation: CommonSense Structured. Ottawa: Ronald P. Frye Publishing.

Lin, G. C. S. (2001). Metropolitan development in a transitional socialist economy: Spatial restructuring in the Pearl River Delta, China. Urban Studies, 38 (3): 383-406. https://doi $10.1080 / 00420980120027429$.

Lin, Y., De Meulder, B. \& Wang, S. (2011). Understanding the 'village in the city' in Guangzhou: economic integration and development issue and their implications for the urban migrant. Urban Studies, 48 (16): 3583-3598. https://doi $10.1177 / 0042098010396239$

Lin, Y. \& De Meulder, B. (2012). A conceptual framework for the strategic urban project approach for the sustainable redevelopment of "villages in the city" in Guangzhou. Habitat International, 36 (3): 380-387. https://doi - 10.1016/j.habitatint.2011.12.001.

Lin, Y., Hao, P. \& Geertman, S. (2015). A conceptual framework on modes of governance for the regeneration of Chinese 'villages in the city'. Urban Studies, 52(10): 1774-1790. https://doi - 10.1177/0042098014540345.

Linehan, J., Gross, M. \& Finn, J. (1995). Greenway planning: developing a landscape ecological network approach. Landscape and Urban Planning, 33 (1-3): 179-193. https://doi 10.1016/0169-2046(94)02017-A. 
Little, C. E. (1990). Greenways for America. Baltimore: Johns Hopkins University Press. Liu, Z. (2017). Urbanism in Transformation: The Planning and Implementation of the Pearl River Delta Greenways (Doctoral dissertation). South China University of Technology, China. (in Chinese)

Liu, K., Siu, K. W. M., Gong, X. Y., Gao, Y. \& Lu, D. (2016). Where do networks really work? The effects of the Shenzhen greenway network on supporting physical activities. Landscape and Urban Planning, 152: 49-58. https://doi - 10.1016/j.landurbplan.2016.04.001.

Liu, B. \& Yu, C. (2001). Greenway Networks Planning of USA and Its Apocalypse to US. Chinese Landscape Architecture, (6): 77-81. (in Chinese)

Louis, A. (2015). Ingredients for a more radical strategic spatial planning. Environment and Planning B: Urban Analytics and City Science, 42(3): 510-525.

Luo, G. \& Wang, Z. (1986). The Origin and Development of Planting Trees on Road Sides in China. Journal of Northwest University, 16 (1): 115-122. (in Chinese)

Ma, X. (2012). The Development and Innovation of Greenways in Guangdong. Landscape Architecture, (3): 71-76. (in Chinese)

Ministry of Housing and Urban-Rural Development (2000). National Garden City Standard. www.mohurd.gov.cn/wjfb/200611/t20061101_156922.html. (in Chinese)

Ministry of Housing and Urban-Rural Development (2016). Greenway planning and design guidelines. www.mohurd.gov.cn/wjfb/201610/t20161014_229168.html. (in Chinese)

Narayanan, C. \& Lau, K. (2014). China - 375 clients talk wages in the PRD. Standard Chartered Bank. from https://research.standardchartered.com/researchdocuments/Pages/ResearchArticle.aspx?\&R $=115122$.

National Greening Committee Office (2000). Green Channel construction will be launched in the state, $100 \%$ greenery along road, railway, river canal, embankment in 2010. Urban Planning Newsreport, (22):3-4. (in Chinese)

National Greening Committee Office (2011). China Land Greening Bulletin 2010. Land 
Greening, (03):2-7. (in Chinese)

Ngo, V. D., Frank, L. D., \& Bigazzi, A. Y. (2018). Effects of new urban greenways on transportation energy use and greenhouse gas emissions: A longitudinal study from Vancouver, Canada. Transportation Research Part D: Transport and Environment, 62, 715725. https://doi-10.1016/j.trd.2018.04.013

Noh, Y. (2019). Does converting abandoned railways to greenways impact neighboring housing prices? Landscape and Urban Planning, 183:157-166. https://doi 0.1016/j.landurbplan.2018.11.002

Ryan, R. L., Fábos, J. G. \& Allan, J. J. (2006). Understanding opportunities and challenges for collaborative greenway planning in New England. Landscape and Urban Planning, 76 (14): 172-191. https://doi - 10.1016/j.landurbplan.2004.09.031.

Savitch, H. V., Gross, J. S. \& Ye, L. (2014). Do Chinese cities break the global mold? Cities, 41, Part B: 155-161. https://doi - 10.1016/j.cities.2014.03.009.

Scudo, K. Z. (2006). The Greenways of Pavia: innovations in Italian landscape planning. Landscape and Urban Planning, 76 (1-4): 112-133. https://doi 10.1016/j.landurbplan.2004.09.030.

Searns, R. M. (1995). The evolution of greenways as an adaptive urban landscape form. Landscape and Urban Planning, 33 (1-3): 65-80. https://doi - 10.1016/01692046(94)02014-7.

Sit, V. F. S. \& Yang, C. (1997). Foreign-investment-induced exo-urbanisation in the Pearl River Delta, China. Urban Studies, 34 (4): 647-677. https://doi - 10.1080/0042098975961.

Smith, D. S. (1993). An overview of Greenways: their history, ecological context and specific functions. In D. S. Smith and P. C. Hellmund (eds). Ecology of Greenways: Design and function of linear conservation areas (pp. 1-22), University of Minnesota press, Minneapolis.

Smith, D. J. (2004). Impacts of roads on ecological networks and integration of conservation and transportation planning: Florida as a case study. In R. H. Jongman and G. Pungetti (Eds.), 
Ecological Networks and Greenways: Concept, Design, Implementation (pp. 73-93).

$$
\text { Cambridge: Cambridge University Press. }
$$

Statistics Bureau of Guangdong Province (1995). Regional economic statistic al material of Guangdong 1980-1993. (in Chinese)

Statistics Bureau of Guangdong Province (2014). Guangdong statistical year book 2013. Beijing: China statistic press. (in Chinese)

Statistics Bureau of Guangdong Province (2015). Guangdong statistical year book 2014. Beijing: China statistic press. (in Chinese)

Tan, K. W. (2006). A greenway network for Singapore. Landscape and Urban Planning, 76 (14): 45-66. https://doi - 10.1016/j.landurbplan.2004.09.040.

Tan, S. \& Zhao, W. (2007). Lvdao guihua yanjiu jinzhan yu zhanwang (Progress and Prospect of Greenway Planning and Research). Chinese Landscape Architecture, (02): 85-89.

Toccolini, A., Fumagalli, N. \& Senes, G. (2006). Greenways planning in Italy: the Lambro River Valley Greenways System. Landscape and Urban Planning, 76 (1-4): 98-111. https://doi 10.1016/j.landurbplan.2004.09.038.

Transport for London (2014). London cycling design standard, Transport for London, tfl.gov.uk/corporate/publications-and-reports

Transport for London (2014). London Greenways Monitoring Report 2010-2014. content.tfl.gov.uk/greenways-final-annual-monitoring-report.pdf

Transport Commission of Shenzhen Municipality (2017). Report of Shenzhen Internet bicycles development (2016.10-2017.03). www.sz.gov.cn/cn/xxgk/zfxxgj/bmdt/201705/t20170509_6668690.htm (in Chinese)

Turner, T. (1998). Landscape Planning and Environmental Impact Design. London - Bristol, PA: UCL Press.

Urban Management Bureau of Shenzhen Municipality (2015). Shenzhen Greenway Data. www.szum.gov.cn/zfwg/tjsj/zxtjxx/index.htm

Von Haaren, C. \& Reich, M. (2006). The German way to greenways and habitat networks. 
Landscape and Urban Planning, 76 (1-4): 7-22. https://doi -

$$
\text { 10.1016/j.landurbplan.2004.09.041. }
$$

Walmsley, A. (1995). Greenways and the making of urban form. Landscape and Urban Planning, 33 (1-3): 81-127. https://doi - 10.1016/0169-2046(95)02015-L.

Weber, S., Boley, B. B., Palardy, N. \& Gaither, C. J. (2017). The impact of urban greenways on residential concerns: Findings from the Atlanta Belt Line Trail. Landscape and Urban Planning, 167: 147-156. https://doi - 10.1016/j.landurbplan.2017.06.009.

World Bank Group (2015). East Asia's Changing Urban Landscape: Measuring a Decade of Spatial Growth. www.worldbank.org

Wu, L., Liu, Y., \& Cheng, H. (2012). Review on the Dynamic Mechanism and Key Elements of Urban-Rural Integrated Development in China. Economic Geography, 32(4): 113-118. (in Chinese)

Wu, F. (2015). Planning for Growth: Urban and Regional Planning in China. Routledge.

Xiong, W. (2015). The characteristics and development of Guangzhou non-motorized traffic at regional scale. The First China Cycling Ecology Conference, Guangzhou.

Xu, W. and Li, B. (2010). Effects of greenway construction on urban-rural integration development in the PRD region. Tropical Geography, 30(5), 515-520. (in Chinese)

Xu, J. \& Yeh, A. G. O. (2012). Re-building Regulation and Re-inventing Governance in the Pearl River Delta, China. Urban Policy and Research, 30 (4): 385-401. https://doi 10.1080/08111146.2012.744717.

Yu, K., Li, D. \& Li, N. (2006). The evolution of Greenways in China. Landscape and Urban Planning, 76 (1-4): 223-239. https://doi - 10.1016/j.landurbplan.2004.09.034.

Yuan, Q. (2015). Is the decline of cycling traffic in Guangzhou inevitable? The First China Cycling Ecology Conference, Guangzhou. (in Chinese)

Zhang, H. (2013). The PRD Spatial Optimization Strategy Research, Guangdong Provincial Department of Housing and Urban-rural Construction. (in Chinese).

Zube, E. H. (1995). Greenways and the US National Park system. Landscape and Urban 
1007

Planning, 33 (1-3): 17-25. https://doi - 10.1016/0169-2046(94)02011-4.

1008 
List of tables

Table 1 The land cover of the Pearl River Delta cities, in square kilometers (2007-10)

Data Source: The Second National Land Resource Investigation (2007-2009)

Table 2 Pearl River Delta general population and land-cover statistics, 1980-2010

Data sources: (a) Statistics Bureau of Guangdong Province, 1995; (b) Statistics Bureau of Guangdong Province, 2014; (c) Department of Land and Resources of Guangdong Province, 2006;

(d) Department of Land and Resources of Guangdong Province, 2011; (e) Zhang, 2013

Table 3 The projected length of regional, municipal, and community greenways in the Pearl River Delta by 2015, in kilometers

Source: Department of Housing and Urban-Rural Development of Guangdong Province, 2011 \& 2013, pp. 322-325

Table 4 The questionnaires used in Zengcheng, Guangzhou

Table 5 Detailed data of Shenzhen greenways 
Table 1 The land cover of the Pearl River Delta cities, in square kilometers (2007-09)

Data Source: The Second National Land Resource Investigation (2007-2009)

\begin{tabular}{llllllll}
\hline City & & & & & & & \multicolumn{2}{c}{$\begin{array}{c}\text { Population } \\
\text { per } \\
\text { square } \\
\text { kilometer }\end{array}$} \\
& Developed land & Forest & & Arable land & & 3,328 \\
Dongguan & 1,057 & $51 \%$ & 345 & $17 \%$ & 126 & $6 \%$ & 1,871 \\
Foshan & 1,265 & $48 \%$ & 741 & $28 \%$ & 379 & $14 \%$ & 1,735 \\
Zhongshan & 604 & $47 \%$ & 302 & $24 \%$ & 127 & $10 \%$ & 5,311 \\
Shenzhen & 852 & $47 \%$ & 586 & $32 \%$ & 32 & $2 \%$ & 944 \\
Zhuhai & 419 & $36 \%$ & 388 & $34 \%$ & 181 & $16 \%$ & 1,774 \\
Guangzhou & 1,594 & $25 \%$ & 2,569 & $41 \%$ & 868 & $14 \%$ & 467 \\
Jiangmen & 913 & $12 \%$ & 4,657 & $60 \%$ & 1,530 & $20 \%$ & 405 \\
Huizhou & 850 & $8 \%$ & 6,792 & $65 \%$ & 1,408 & $13 \%$ & 265 \\
Zhaoqing & 799 & $6 \%$ & 10,505 & $76 \%$ & 1,421 & $10 \%$ & \\
\hline
\end{tabular}


Table 2 Pearl River Delta general population and land-cover statistics, 1980-2010

Data sources: (a) Statistics Bureau of Guangdong Province, 1995; (b) Statistics Bureau of Guangdong Province, 2014; (c) Department of Land and Resources of Guangdong Province, 2006;

(d) Department of Land and Resources of Guangdong Province, 2011; (e) Zhang, 2013

\begin{tabular}{llllll}
\hline & 1980 & 1990 & 2000 & 2005 & 2010 \\
\hline Population (millions) & $18.28^{\mathrm{a}}$ & $23.70^{\mathrm{b}}$ & $42.90^{\mathrm{b}}$ & $45.47^{\mathrm{b}}$ & $56.13^{\mathrm{b}}$ \\
$\quad$ Urban residents (millions) & $\mathrm{b} / \mathrm{a}$ & 16.97 & 29.81 & 35.16 & 46.46 \\
$\begin{array}{l}\text { Registered household population } \\
\text { (millions) }\end{array}$ & $\mathrm{n} / \mathrm{a}$ & 23.72 & 25.64 & 27.63 & 31.06 \\
$\begin{array}{l}\text { Unregistered migrants (millions) } \\
\text { Arable land (square kilometers) }\end{array}$ & $\mathrm{n} / \mathrm{a}$ & $\mathrm{n} / \mathrm{a}$ & 17.26 & 17.84 & 25.07 \\
Built-up area (square kilometers) & $\mathrm{n} / \mathrm{a}$ & $2,813^{\mathrm{e}}$ & $\mathrm{n} / \mathrm{a}$ & $8,264^{\mathrm{c}}$ & $10,420^{\mathrm{d}}$ \\
\hline
\end{tabular}


Table 3 The projected length of regional, municipal, and community greenways in the Pearl River Delta by 2015, in kilometers

Source: Department of Housing and Urban-Rural Development of Guangdong Province, 2011 \& 2013, pp. 322-325

\begin{tabular}{|c|c|c|c|c|c|}
\hline & \multicolumn{3}{|c|}{ Provincial greenways } & \multirow[b]{2}{*}{$\begin{array}{l}\text { Municipal } \\
\text { greenways }\end{array}$} & \multirow[b]{2}{*}{$\begin{array}{l}\text { Community } \\
\text { greenways }\end{array}$} \\
\hline & $\begin{array}{l}\text { Ecological } \\
\text { greenways }\end{array}$ & $\begin{array}{l}\text { Countryside } \\
\text { greenways }\end{array}$ & $\begin{array}{l}\text { Urban } \\
\text { greenways }\end{array}$ & & \\
\hline Guangzhou & 103 & 230 & 255 & 551 & 971 \\
\hline Shenzhen & 148 & 135 & 52 & 500 & 730 \\
\hline Zhuhai & 13 & 156 & 56 & 411 & 440 \\
\hline Foshan & 45 & 208 & 163 & 710 & 860 \\
\hline Huizhou & 54 & 221 & 114 & 705 & 566 \\
\hline Dongguan & 75 & 84 & 66 & 565 & 747 \\
\hline Zhongshan & 0 & 82 & 100 & 264 & 320 \\
\hline Jiangmen & 120 & 235 & 36 & 832 & 383 \\
\hline Zhaoqing & 221 & 155 & 43 & 930 & 248 \\
\hline Pearl River Delta (total) & 779 & 1,506 & 885 & 5,468 & 5,265 \\
\hline
\end{tabular}


Table 4 The questionnaires used in Zengcheng, Guangzhou

\begin{tabular}{|c|c|c|}
\hline \multicolumn{3}{|c|}{ Part 1: Tourist questionnaire (478 copies) } \\
\hline & Question & Response \\
\hline 1 & Where do you come from? & $\begin{array}{l}\text { Zengcheng (i.e., local): } 32 \% \\
\text { Other districts in Guangzhou: } 31 \% \\
\text { Dongguan: } 17 \% \\
\text { Shenzhen: } 6 \% \\
\text { Foshan: } 2 \% \\
\text { Other cities in Guangdong: } 10 \% \\
\text { Other Provinces: } 2 \%\end{array}$ \\
\hline 2 & $\begin{array}{l}\text { What is your primary purpose of greenway use? } \\
\text { a) natural environment b) outdoor exercise } \\
\text { c) group recreation d) family leisure activity }\end{array}$ & $\begin{array}{l}\text { Natural environment: } 37 \% \\
\text { Family leisure activity: } 28 \% \\
\text { Outdoor exercise: } 24 \%\end{array}$ \\
\hline \multicolumn{3}{|c|}{ Part 2: Resident questionnaire (127 copies) } \\
\hline & Question & Response \\
\hline 3 & $\begin{array}{l}\text { What was your family's annual per capita income } \\
\text { five years ago? a) }<10,000 \text { b) } 10,000-50,000 \mathrm{c} \text { ) } \\
50,000-100,000 \text { d) }>100,000\end{array}$ & $\begin{array}{l}<10,000: 52 \% \\
10,000-50,000: 37 \% \\
>50,000: 11 \%\end{array}$ \\
\hline 4 & $\begin{array}{l}\text { What is your family's annual per capita income } \\
\text { now? a) }<10,000 \text { b) } 10,000-50,000 \text { c) } 50,000- \\
100,000 \text { d) }>100,000\end{array}$ & $\begin{array}{l}<10,000: 38 \% \\
10,000-50,000: 37 \% \\
>50,000: 26 \%\end{array}$ \\
\hline 5 & $\begin{array}{l}\text { What was the primary source of your household } \\
\text { income five years ago? } \\
\text { a) farming \& cultivation b) self-owned tourism } \\
\text { restaurant c) work outside the village d) private } \\
\text { industries }\end{array}$ & $\begin{array}{l}\text { Self-owned tourism restaurant: } 2 \% \\
\text { Work outside the village: } 53 \% \\
\text { Farming \& cultivation: } 33 \%\end{array}$ \\
\hline 6 & $\begin{array}{l}\text { What is the primary source of your household } \\
\text { income now? } \\
\text { a) farming \& cultivation b) self-owned tourism } \\
\text { restaurant c) work outside the village d) private } \\
\text { industries }\end{array}$ & $\begin{array}{l}\text { Self-owned tourism restaurant: } 23 \% \\
\text { Work outside the village: } 43 \% \\
\text { Farming \& cultivation: } 18 \%\end{array}$ \\
\hline 7 & $\begin{array}{l}\text { What do you think is the primary benefit of } \\
\text { greenways? a) increased income b) improved } \\
\text { environment c) created employment d) improved } \\
\text { local image e) provide daily exercise space f) } \\
\text { provide public services }\end{array}$ & $\begin{array}{l}\text { Increased income: } 25 \% \\
\text { Provides daily exercise space: } 25 \% \\
\text { Improved environment: } 15 \% \\
\text { Improved local image: } 15 \%\end{array}$ \\
\hline 8 & $\begin{array}{l}\text { What is the primary purpose of your greenway } \\
\text { use? a) business b) daily commuting } \\
\text { c) outdoor activity d) family activity }\end{array}$ & $\begin{array}{l}\text { Outdoor exercise: } 42 \% \\
\text { Business: } 23 \% \\
\text { Family activity: } 21 \%\end{array}$ \\
\hline
\end{tabular}


9 How often did you engage in outdoor leisure Almost never: 31\% activities five years ago? Occasionally: $39 \%$

a) almost never b) occasionally c) less than once Less than once a week: $26 \%$ a week d) multiple times a week Multiple times a week: $4 \%$

10 How often do you engage in outdoor leisure Almost never: 7\% activities now?

Occasionally: $50 \%$

a) almost never b) occasionally c) less than once Less than once a week: $27 \%$

a week d) multiple times a week

Multiple times a week: $16 \%$ 
Table 5 Detailed data of Shenzhen greenways, in kilometers

\begin{tabular}{lrrrr}
\hline & $\begin{array}{r}\text { Regional } \\
\text { greenways }\end{array}$ & $\begin{array}{r}\text { Municipal } \\
\text { greenways }\end{array}$ & $\begin{array}{r}\text { Community } \\
\text { greenways }\end{array}$ & Total \\
\hline 1. Locating spaces & & & & \\
$\quad$ off-road greenways & 120.8 & 122.6 & 41.5 & 284.9 \\
in-roadway greenways & 86.7 & 93.7 & 192.9 & 373.3 \\
$\quad$ on-sidewalk greenways & 129.8 & 419.9 & 728.0 & 1277.7 \\
\hline 2. Width of green corridors & & & & \\
1-12 meters & 64.1 & 356 & 756.5 & 1176.6 \\
12-30 meters & 1.8 & 18.6 & 43.2 & 63.6 \\
30-60 meters & 10.2 & 21.6 & 7.6 & 39.4 \\
60-100 meters & 5.8 & 4.4 & 5.7 & 15.9 \\
more than 100 meters & 257.3 & 233.8 & 149.3 & 640.4 \\
\hline 3. Improvement initiatives & & & & \\
only symbols & 213.6 & 354.7 & 347.6 & 915.9 \\
pavement or construction & 125.6 & 279.8 & 614.6 & 1020.0 \\
\hline 4. Pavement & & & & \\
bricks & 132.7 & 336 & 556.1 & 1024.8 \\
asphalt & 113.7 & 231.2 & 256.9 & 601.8 \\
cement & 74.1 & 49.6 & 145.8 & 269.5 \\
sand-gravel & 18.7 & 17.6 & 3.5 & 39.8 \\
\hline 5. Management & & & & \\
Scenic parks & 12.8 & 39.7 & 0 & 52.5 \\
Sub-district offices & 181.0 & 129.5 & 410 & 720.5 \\
District bureaus & 145.4 & 436.9 & 498.3 & 1080.6 \\
Municipal departments & 0 & 28.4 & 53.9 & 82.3 \\
\hline
\end{tabular}




\section{List of figures}

Figure 1 A conceptual framework: greenways as a new planning strategy

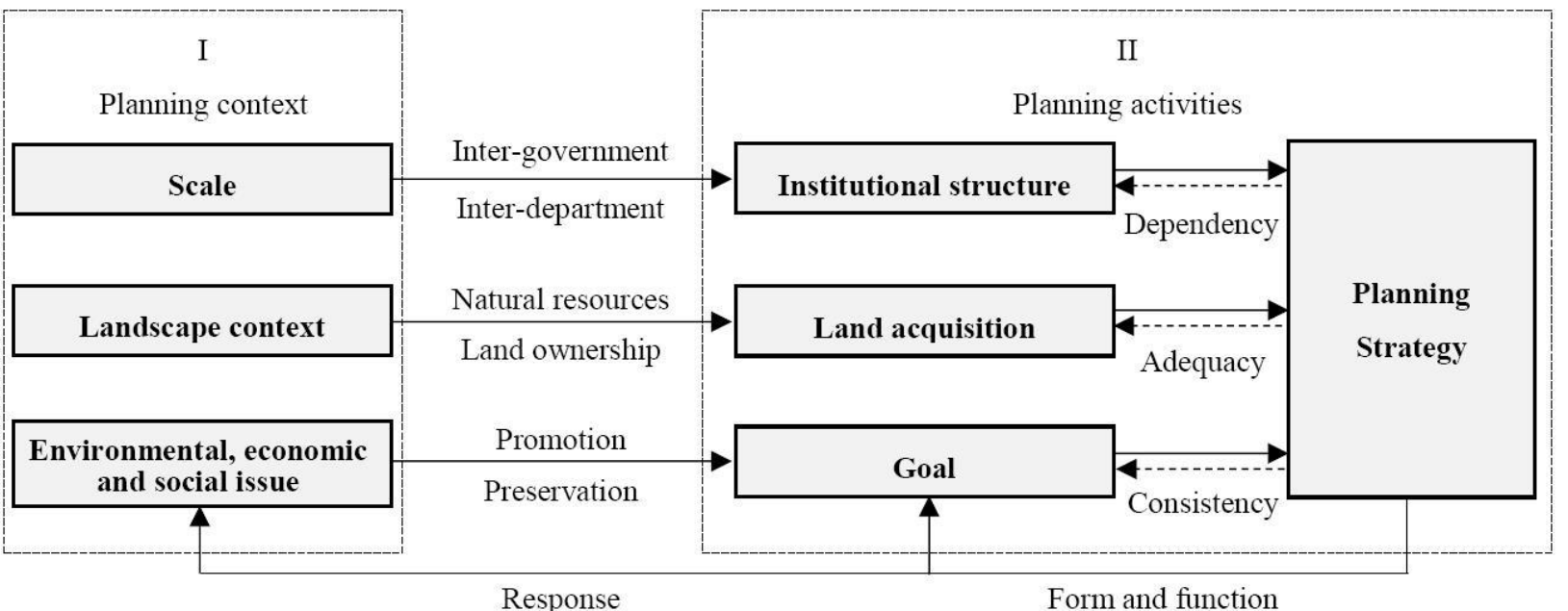

Figure 2 The Pearl River Delta Greenway Network

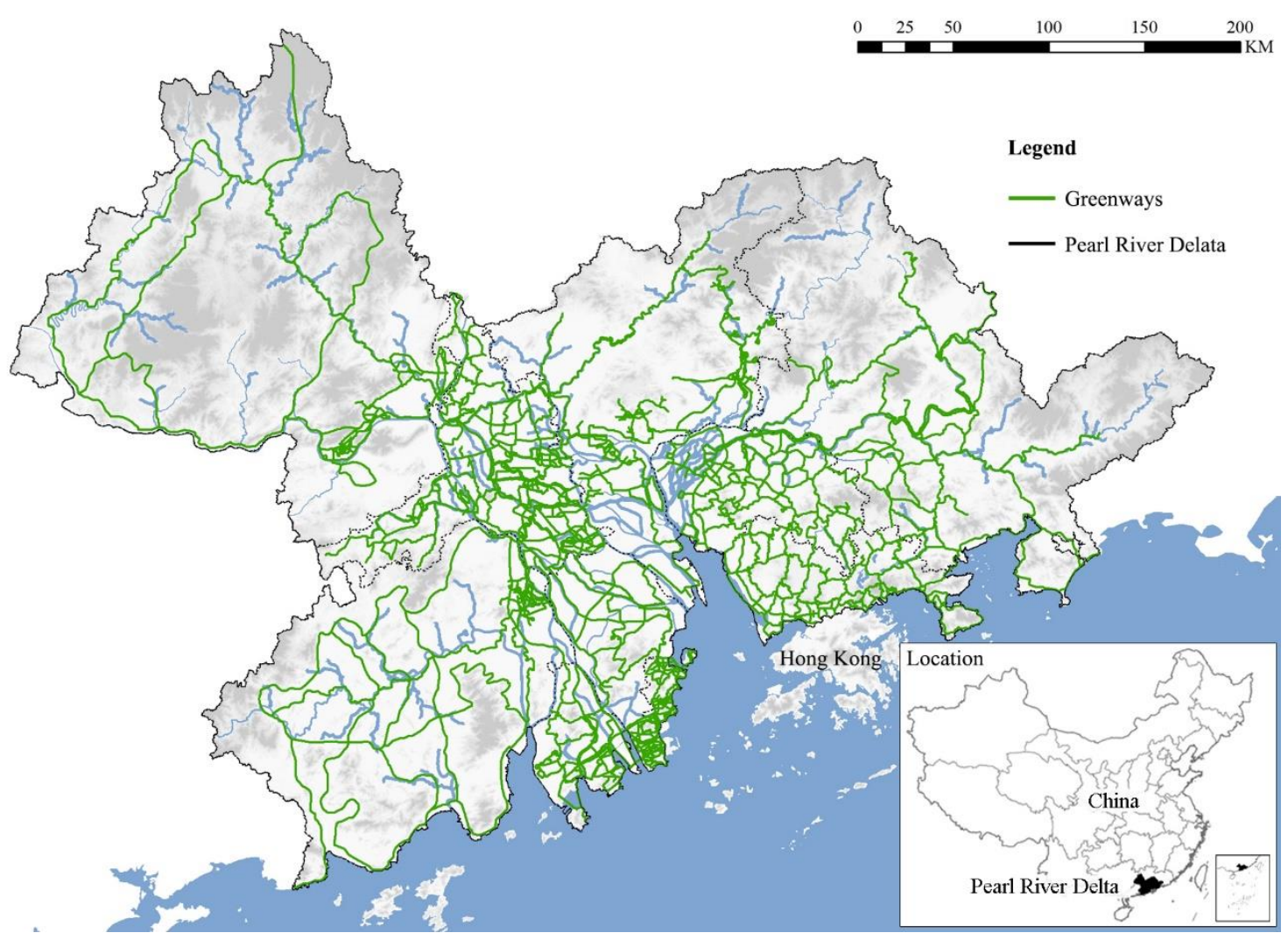


Figure 3 Collectively owned lychee orchard and lotus ponds as a shared landscape in Zengcheng,

\author{
Guangzhou
}

(Source: photos by the first author)
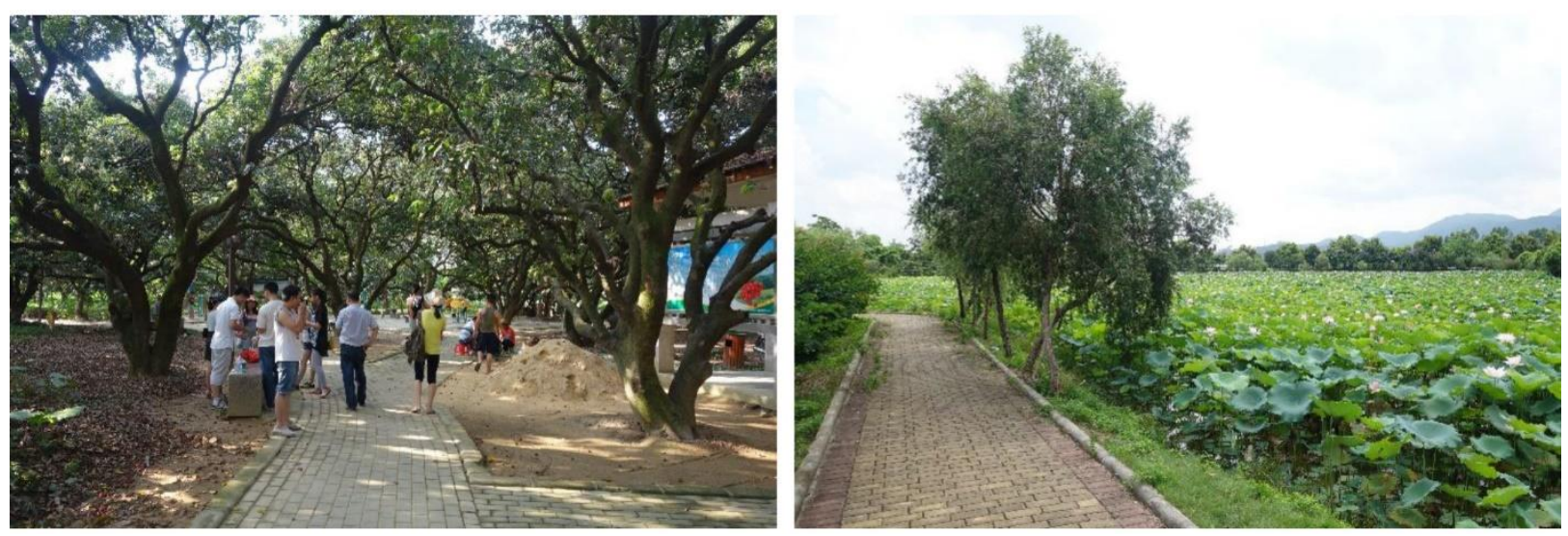

Figure 4 Institutional structure of the Pearl River Delta greenways

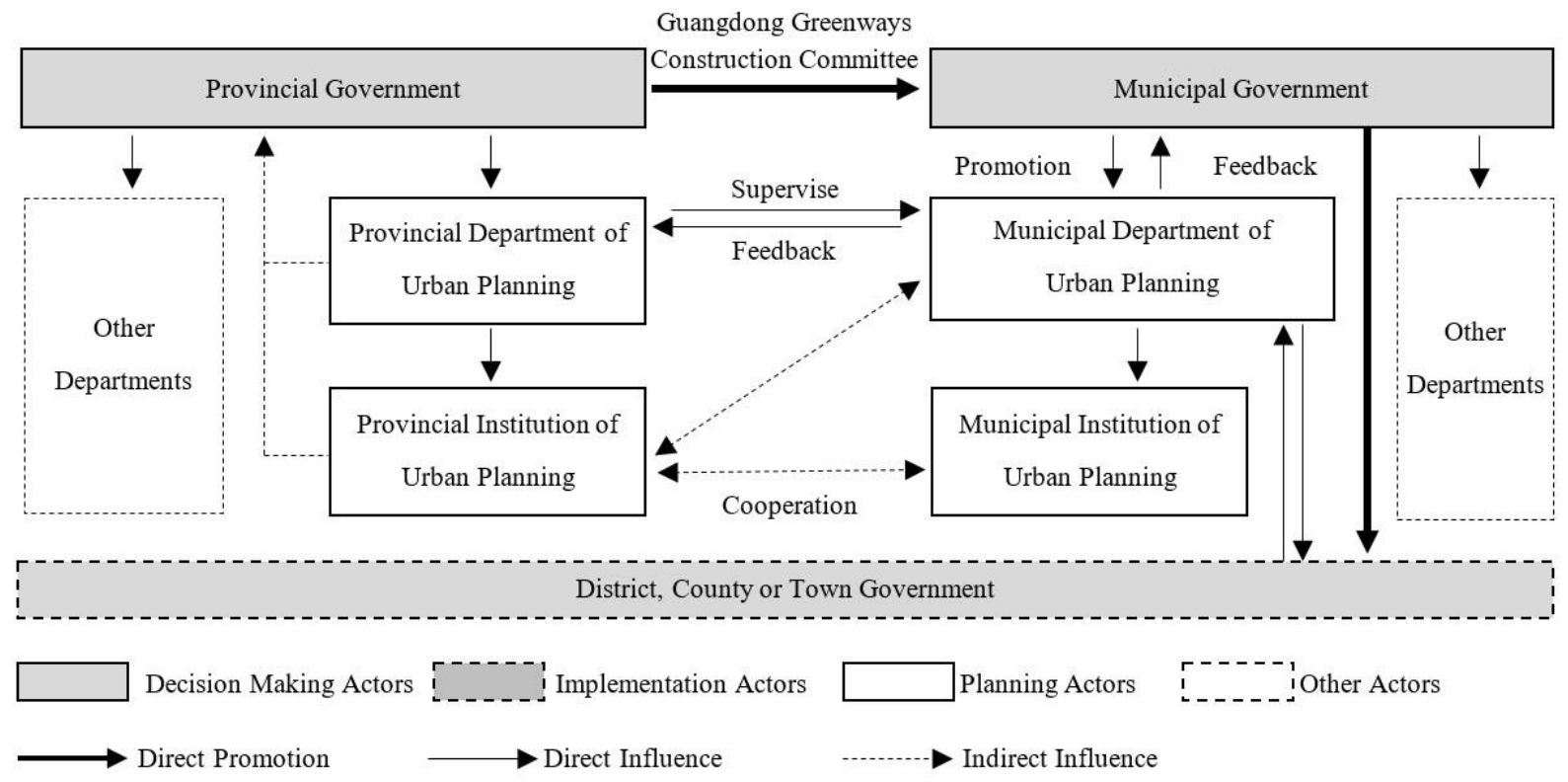


Figure 5 Street views before (left, 2011) and after (right, 2014) the implementation of the greenways in Shenzhen's Xingye Street (above) and Xinping Street (below).

(Source: map.qq.com)

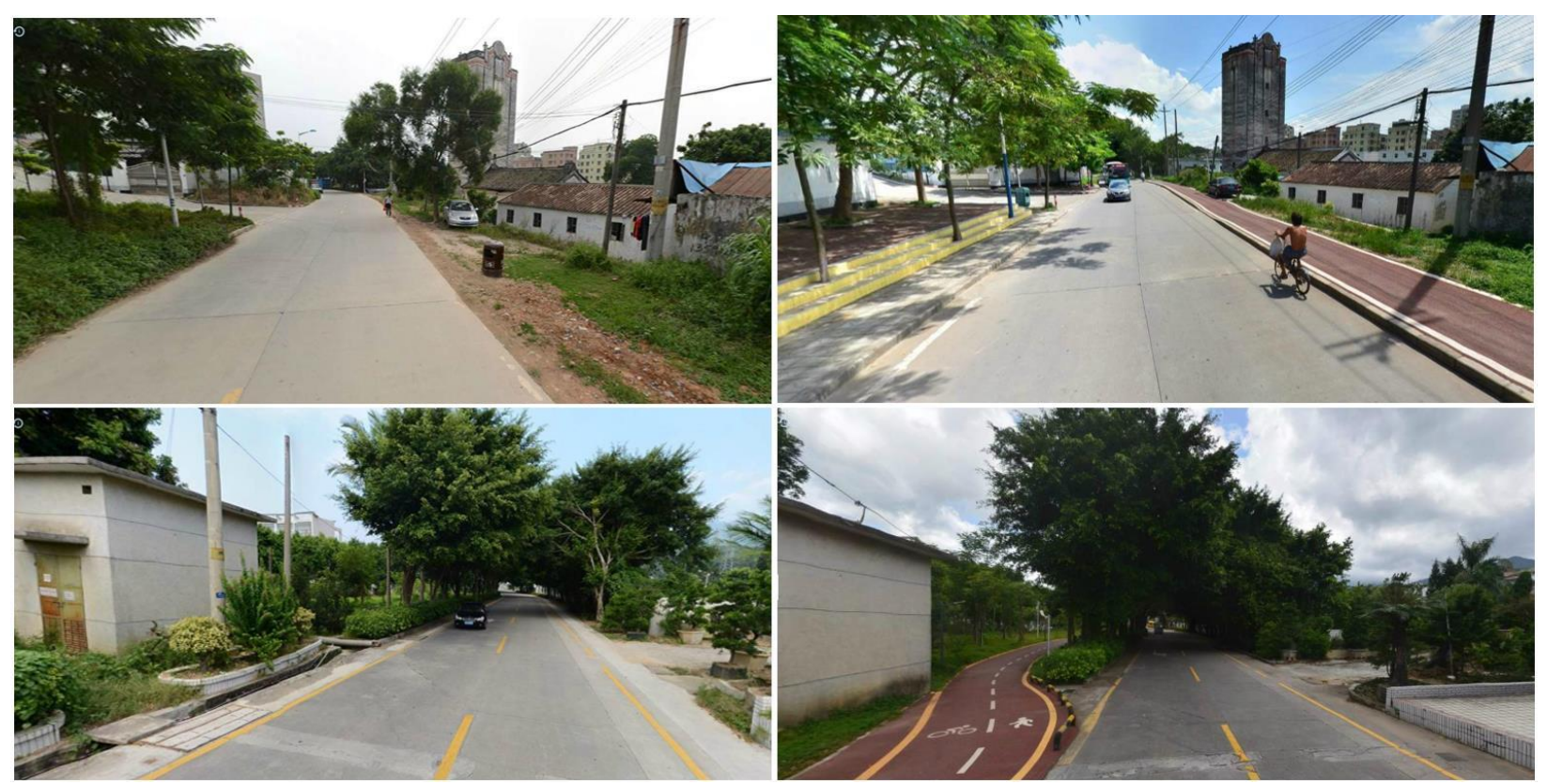

Figure 6 Public bikes in racks next to a community greenway in Yantian District, Shenzhen (Source: photos by the first author)

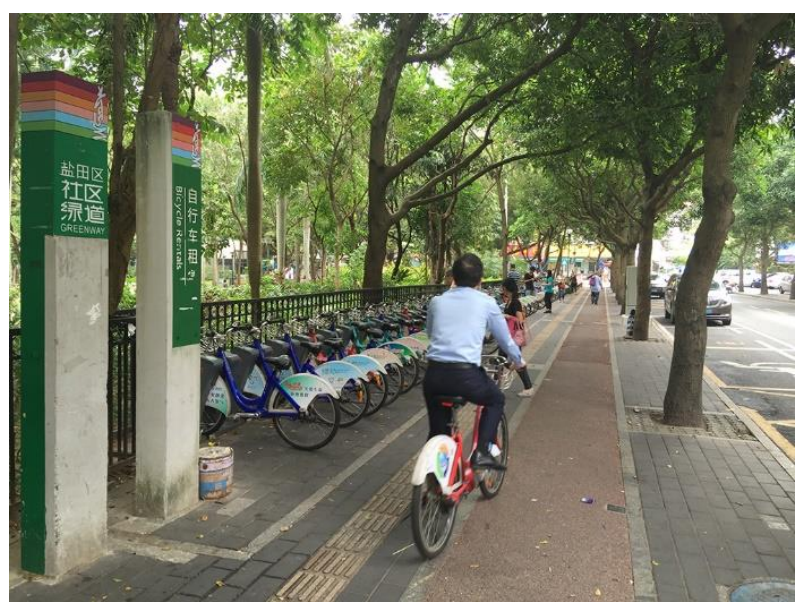


Figure 7 Jinzhong greenway (left) and bicycle rental stores at the entrance (right)

(Source: photo by the first author)
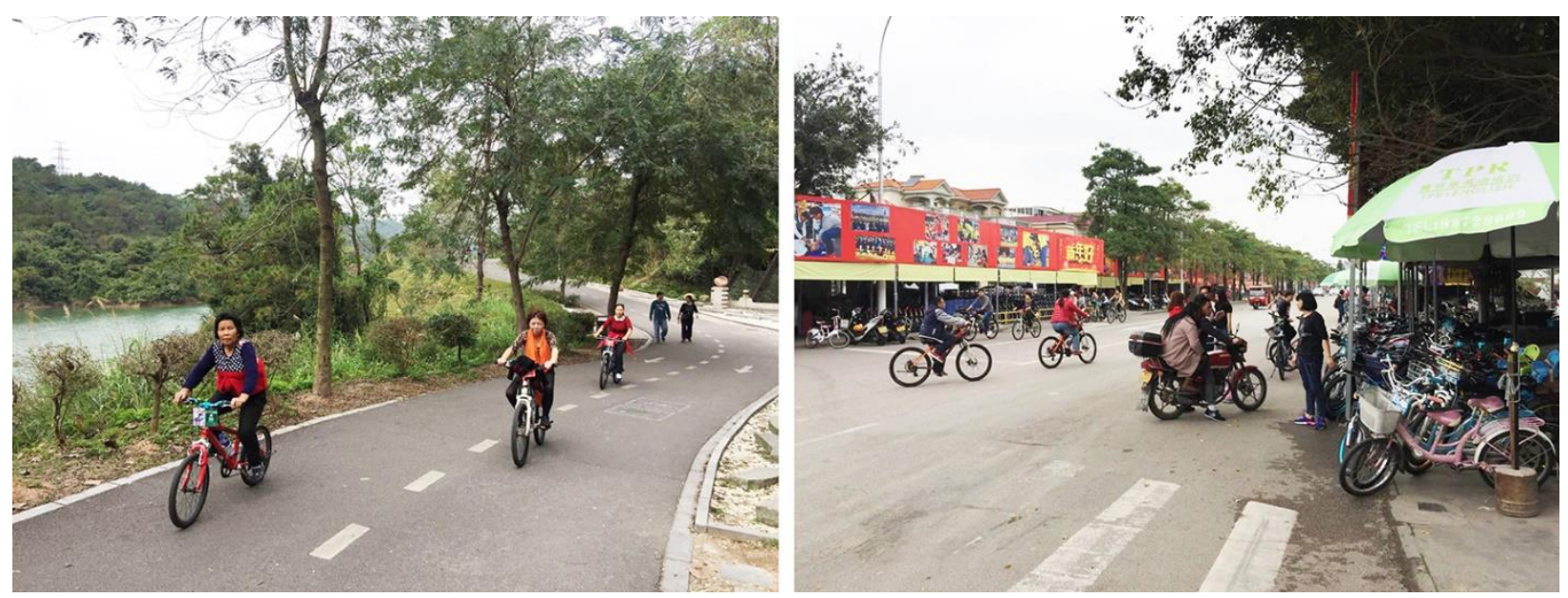

Figure 8 Greenway tourists riding public quadricycles past restaurants in Liantang Village

(Source: photo by the first author)

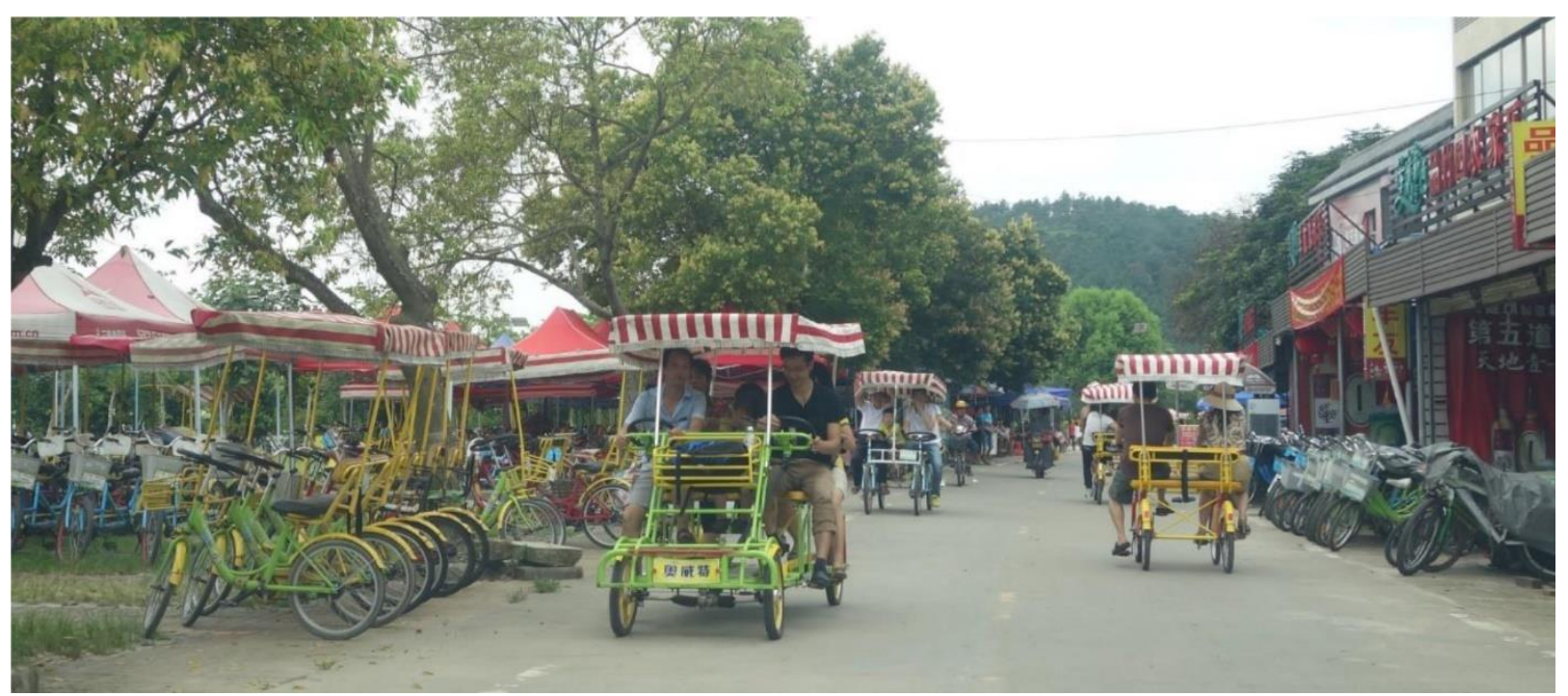


Figure 9 Shenzhen greenways overlaid with built-up area

Source: Shenzhen Greenway Map 2014

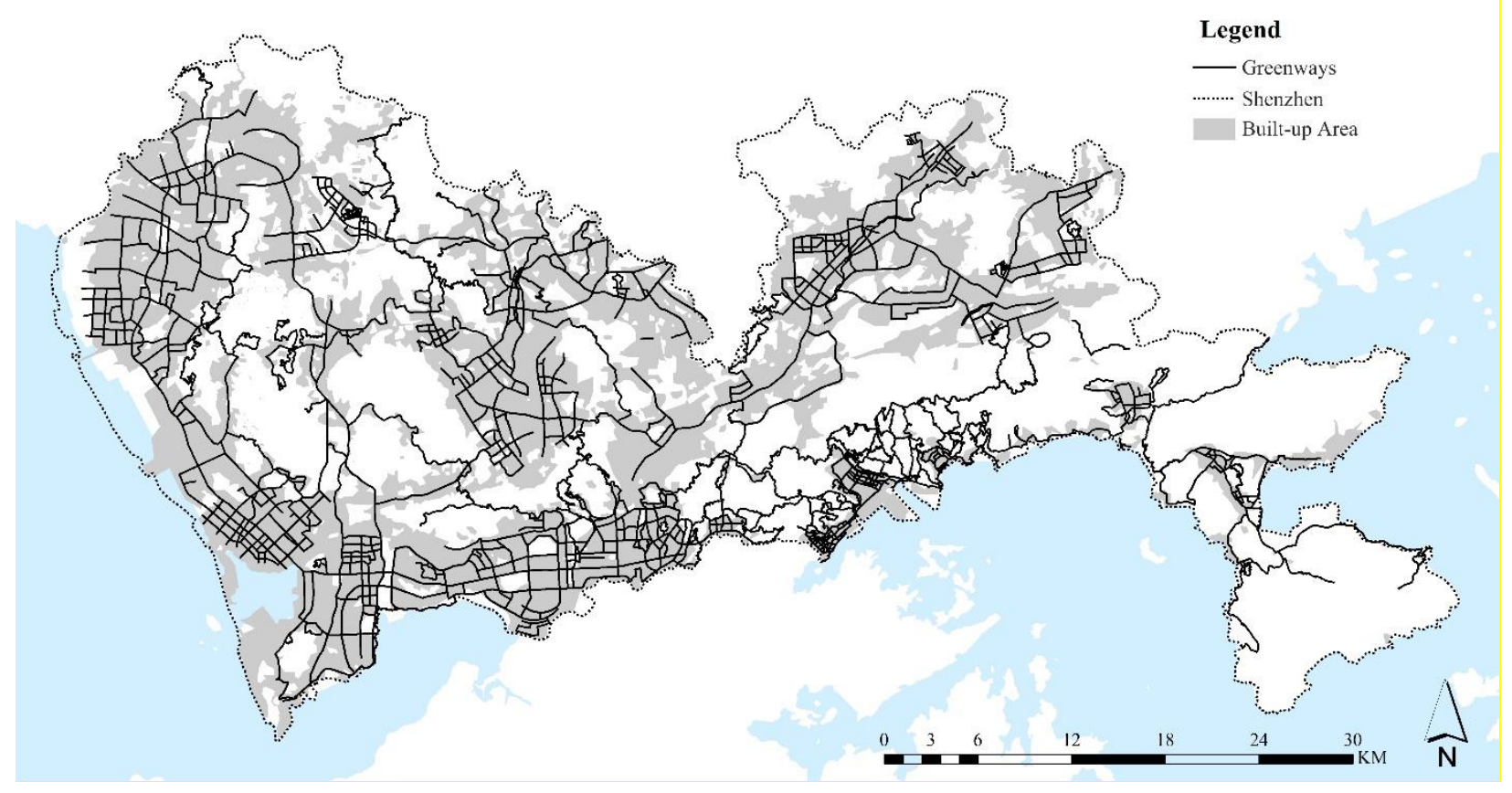


Figure 10 Typical greenway spaces in Shenzhen

(Source: photos by the first author)
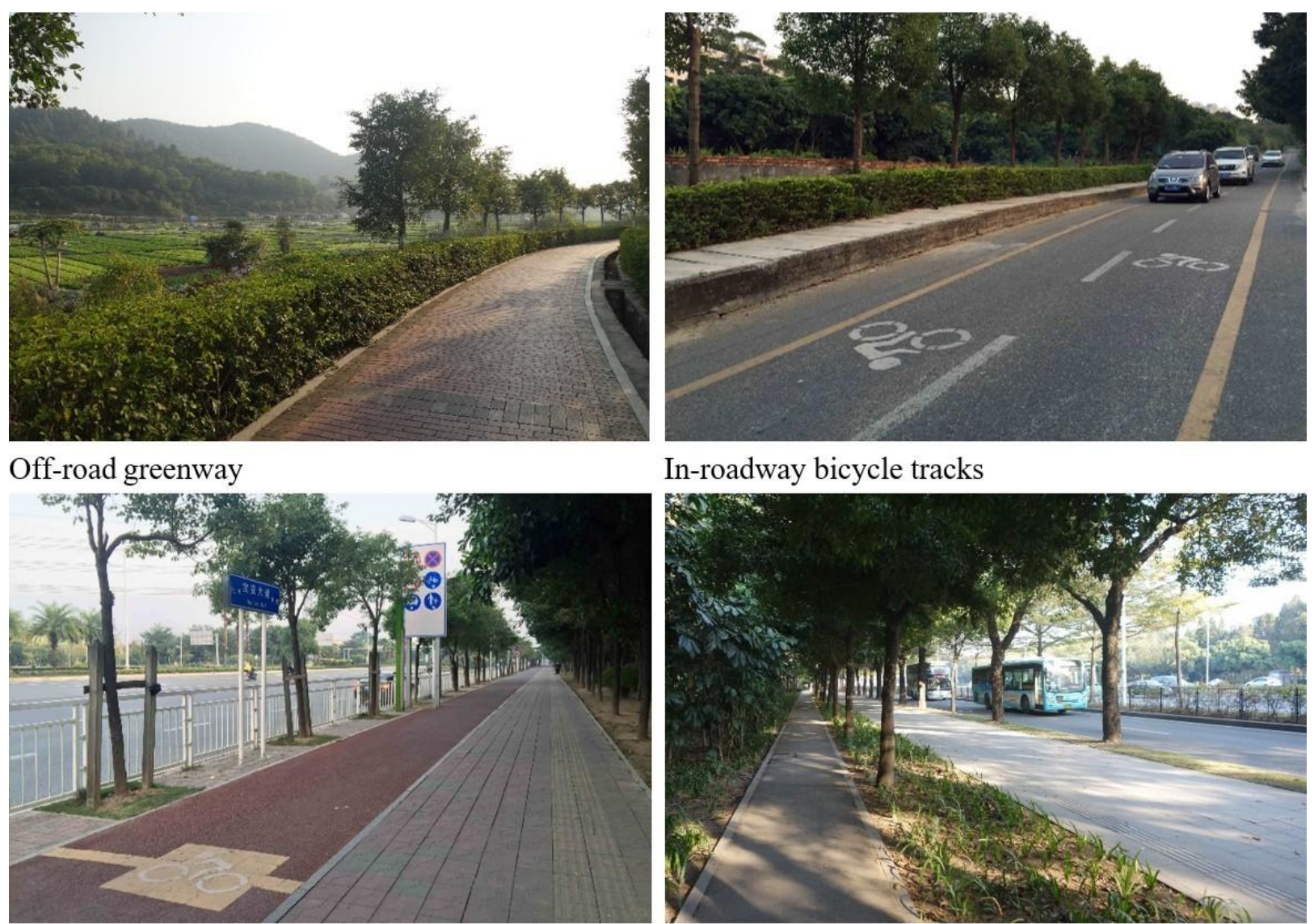

In-roadway bicycle tracks

On-sidewalk bicycle track

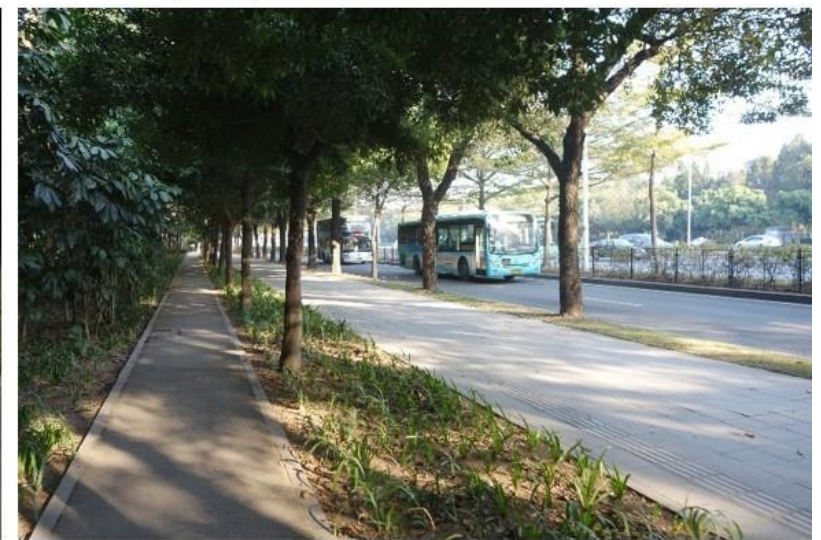

On-sidewalk buffered bicycle track 
Figure 11 Zengcheng greenways and land use types in the 1000-meter-wide corridors along greenways
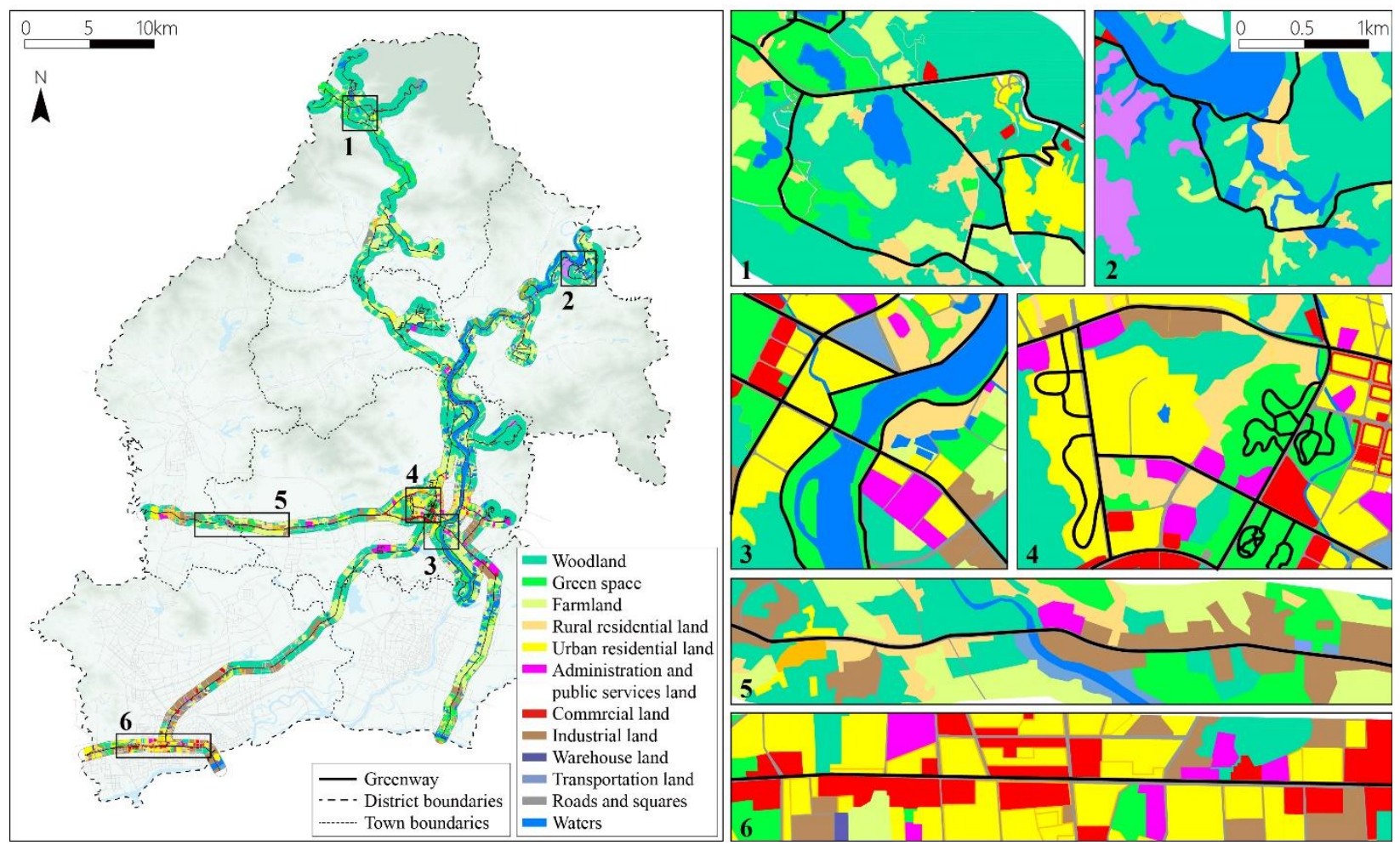